\title{
MELT RATE IMPROVEMENT FOR DWPF MB3: Summary and Recommendations (U)
}

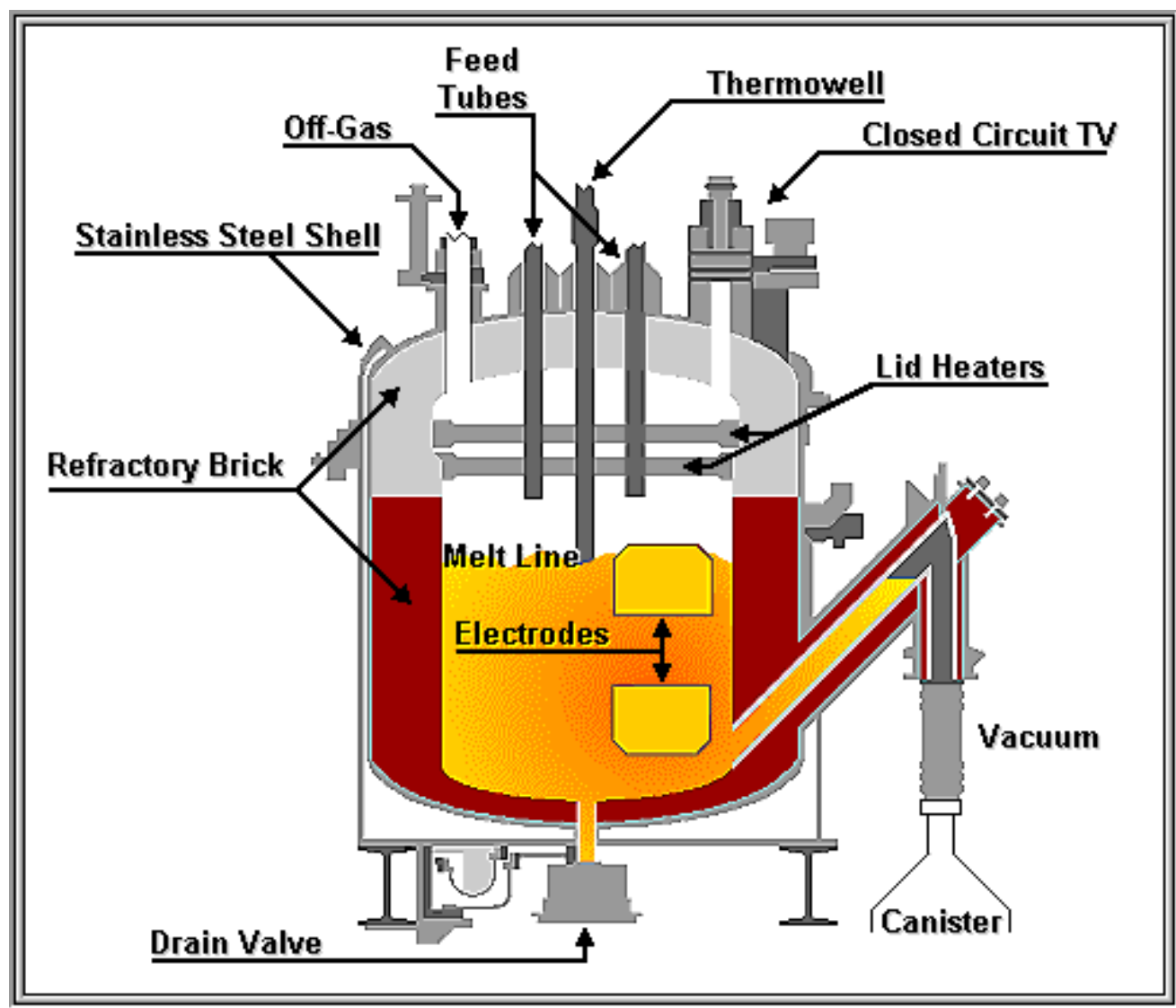

D. P. Lambert

T. H. Lorier

D. K. Peeler

M. E. Stone 
This document was prepared in conjunction with work accomplished under Contract No.

DE-AC09-96SR18500 with the U.S. Department of Energy.

\section{DISCLAIMER}

This report was prepared as an account of work sponsored by an agency of the United States Government. Neither the United States Government nor any agency thereof, nor any of their employees, makes any warranty, express or implied, or assumes any legal liability or responsibility for the accuracy, completeness, or usefulness of any information, apparatus, product or process disclosed, or represents that its use would not infringe privately owned rights. Reference herein to any specific commercial product, process or service by trade name, trademark, manufacturer, or otherwise does not necessarily constitute or imply its endorsement, recommendation, or favoring by the United States Government or any agency

thereof. The views and opinions of authors expressed herein do not necessarily state or reflect those of the United States Government or any agency thereof.

This report has been reproduced directly from the best available copy.

Available for sale to the public, in paper, from: U.S. Department of Commerce, National Technical Information Service, 5285 Port Royal Road, Springfield, VA 22161, phone: (800)

553-6847, fax: (703) 605-6900, email: orders@ntis.fedworld.gov online ordering: http://www.ntis.gov/ordering.htm

Available electronically at http://www.doe.gov/bridge

Available for a processing fee to U.S. Department of Energy and its contractors, in paper, from: U.S. Department of Energy, Office of Scientific and Technical Information, P.O. Box 62, Oak Ridge, TN 37831-0062, phone: (865 ) 576-8401, fax: (865) 576-5728, email: reports@ adonis.osti.gov 
Keywords: DWPF

Vitrification, Bed

Expansion Crucible,

Melt Rate

Retention: Permanent

\section{MELT RATE IMPROVEMENT FOR DWPF MB3: Summary and Recommendations $(U)$}
D. P. Lambert
T. H. Lorier
D. K. Peeler
M. E. Stone

Publication Date: May 8, 2001

Westinghouse Savannah River Company

Savanah River Site

Aiken, SC 29808

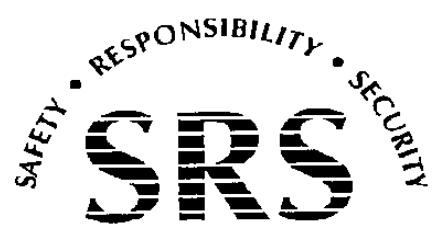

PREPARED FOR THE U.S. DEPARTMENT OF ENERGYUNDER CONTRACT NO. DE-ACO9-96SR18500 
WSRC-TR-2001-00148

This page intentionally left blank. 


\section{APPROVALS}

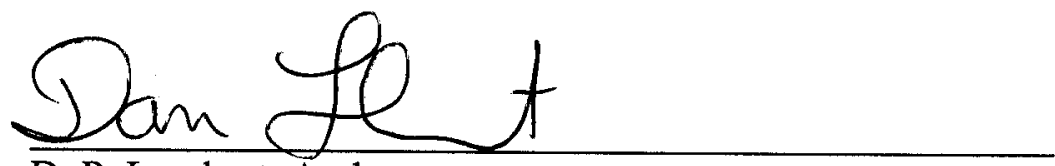

D. P. Lambert, Author Immobilization Technology Section

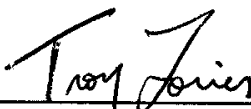

T. H. Lorier, Author

Immobilization Technology Section

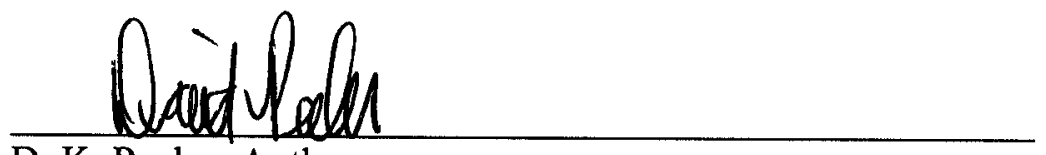

D. K. Peeler, Author

Immobilization Technology Section

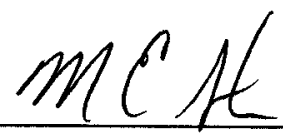

M. E. Stone, Author

Immobilization Technology Section

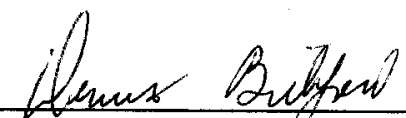

D. F. Bickford, Technical Reviewer Immobilization Technology Section

D. C. Witt, Technical Reviewer

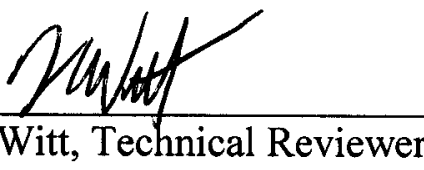

Immobilization Technology Section

Shava f.n lama

S. L. Marra, Manager

Glass Form \& Process Development Group - DWPF

Evtoetzahutes

E. W. Holtzscheiter, Manager

Immobilization Technology Section

$$
5-10-01
$$

Date

$$
\frac{5-10-01}{\text { Date }}
$$

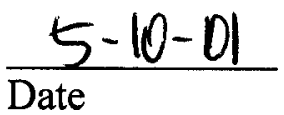

$\frac{5-10-01}{\text { Date }}$

$\frac{5 \% 10 \% 1}{\text { Date }}$

$\frac{5 / 22 / 01}{\text { Date }}$

$\frac{5 / 10 / 01}{\text { Date }}$

$5 / 15 / 01$

Date 
WSRC-TR-2001-00148

\section{ACKNOWLEDGMENTS}

The authors would like to thank the other members of the melt-rate team, which includes Denny Bickford, Hector Guerrero, Carol Jantzen, Sharon Marra, Jim Sproull, and Doug Witt, for their insightful technical direction.

We also appreciate the assistance of the many SRTC technicians, their supervisors and interns that have supported these tasks, especially Frances Williams, Joe Wheeler, Sarah Brown, Tony Burckhalter, Jon DuVall, Jamal Josephs, Sammie King, Debbie Marsh, Mary Moss, Daniel Pittman, Irene Reamer, Pat Toole, Vickie Williams, and Phyllis Workman.

The technical support from John Vienna, Joe Perez, and Pavel Hrma (PNNL) was invaluable.

We especially appreciated the direction and support from the DWPF and HLW engineers, especially Dick O'Driscoll, Richard Edwards, Hank Elder, Dan Iverson, Michael Norton, and John Occhipinti.

The glass shop technicians, Gary Dobos and Curt Sexton, provided capable and timely help in sectioning the crucibles and beakers and preparing glassware to support the use of the borescope to view the melt-rate furnace experiments. Thanks to Jeff Siler for his assistance in setting up the camera equipment that was used to video the melt-rate furnace testing. We appreciated the help from Tim Jones and Nick Odom for melt-rate furnace modifications.

Sharon Marra and William Holtzscheiter (TFA TIM for Immobilization) provided technical management and guidance of this task. Stacie Owens provided efficient and competent clerical support for this task. This study was co-funded by the Department of Energy through the Defense Waste Processing Facility and by the Office of Science and Technology through the Tanks Focus Area. Westinghouse Savannah River Company is operated for the U.S. Department of Energy under Contract No. DE-AC09-96SR18500. 
WSRC-TR-2001-00148

\section{TABLE OF CONTENTS}

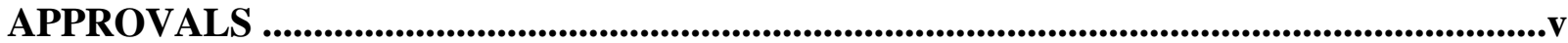

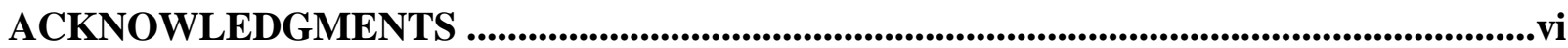

TABLE OF CONTENTS....................................................................................................vii

LIST OF FIGURES …......................................................................................................viii

LIST OF TABLES .......................................................................................................................................... viii

EXECUTIVE SUMMARY....................................................................................................................

RECOMMENDATIONS.............................................................................................................................

FUTURE WORK ..........................................................................................................................................

ACRONYMS.......................................................................................................................................................iii

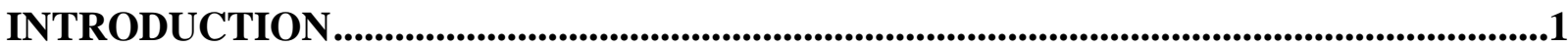

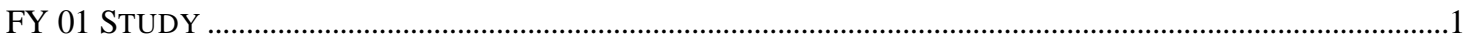

RECOMMENDED PROCESSING FOR DWPF MACROBATCH 3 .......................................................................

LIMITATIONS OF TESTING.....................................................................................................................2

OVERVIEW OF SOURCE DOCUMENTS .............................................................................3

INCENTIVE, FOAMING THEORY, AND MITIGATION TECHNIQUES TO IMPROVE MELT RATE............................

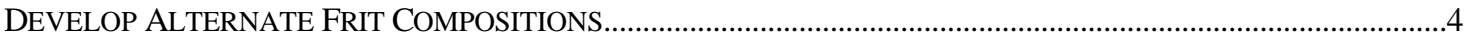

PREPARATION OF FRITS FOR CRUCIBLE AND MELT-RATE FURNACE TESTING..........................................6

DEVELOPMENT OF MELTER FEEDS FOR MELT -RATE FURNACE TESTING......................................................

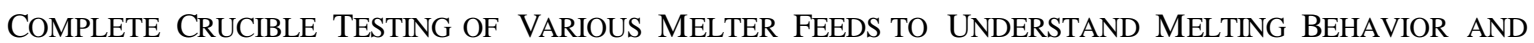

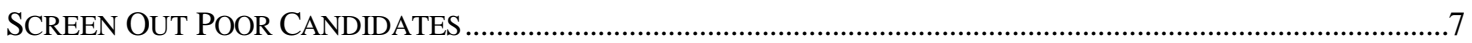

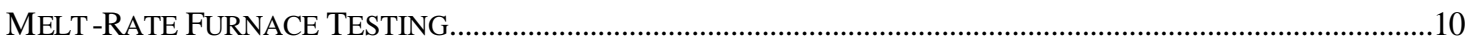

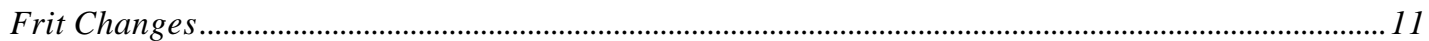

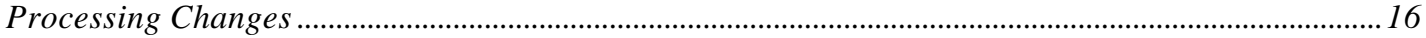

Modifications to Sludge Produced in the Extended Sludge Processing (ESP) Facility ........................16

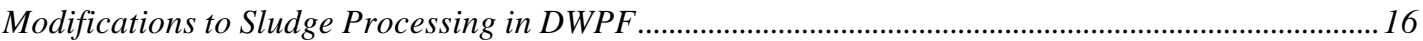

EVALUATE PERFORMANCE OF GLASSES USING GLASS MODELS AND PERFORMANCE TESTING...................17

EVALUATION OF ALTERNATE FRIT COMPOSITIONS ...................................................20

SUMMARY OF TEST RESULTS ....................................................................................................20

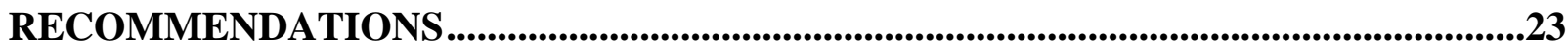

CONCLUSIONS .................................................................................................................................23

REFERENCES ........................................................................................................................................25

DISTRIBUTION:...................................................................................................................................26 
WSRC-TR-2001-00148

\section{LIST OF FIGURES}

Figure 1 - Comparison of Sectioned Crucibles of Frit 200 and 304..................................

Figure 2 - Sectioned Beaker from Nominal Macrobatch (Frit 200) Melt-Rate Furnace Test

Figure 3 - Sectioned Beaker from Frit 304 Run.............................................................11

Figure 4 - Graph of Melt Rate versus Alkali Content for MB3 Glasses ............................15

Figure 5 - Schematic of $\Delta \mathrm{G}_{\mathrm{P}}$ versus Log NL [B] $(\mathrm{g} / \mathrm{L})$ for Various Frits ........................19

\section{LIST OF TABLES}

Table 1 - Reports Used as Sources for the Present Report.

Table 2 - Compositions (mass percent) of Existing Frits and Additional Recommended Frits

Table 3 - Frit Oxide Composition of Twelve Recommended Frits (First Cut)

Table 4 - Melt-Rate Estimate of Recommended Frits Based on Melt-Rate Furnace Tests12

Table 5 - Composition of Frits 320, 320-A and 304 ......................................................13

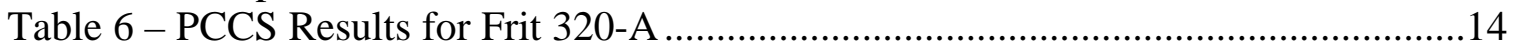

Table 7 - Melt-Rate Estimate of Process Changes based on Melt-rate Furnace Tests......17

Table 8 - Melt-Rate Estimate of Adding Sugar, Based on Melt-Rate Furnace Tests........17

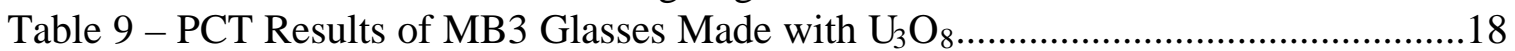

Table 10 - PAR Limits for Various Glass Properties .....................................................20

Table 11 - Summary of Results for FY01 Melt-Rate Tests..............................................22 
WSRC-TR-2001-00148

\section{EXECUTIVE SUMMARY}

The objective for this task is to understand and apply the control of glass batch chemistry (frit composition) and/or changes in chemical processing strategies to improve the overall melting process for Macrobatch 3 (MB3) (Defense Waste Processing Facility (DWPF) sludge-only processing). For melt rate limited systems, a small increase in melting efficiency translates into substantial savings by reducing operational costs without compromising the quality of the final waste product.

This report summarizes the key information collected during the FY01 melt-rate testing completed to support the conclusion that switching from Frit 200, the frit currently used to prepare all the glass produced in radioactive processing, to Frit 320 should improve the melt rate during processing of DWPF MB3 sludge (Note: MB3 is referred to as Sludge Batch 2 in the High-Level Waste System Plan). The report also includes recommendations that should be addressed prior to implementation of the new frit and future research that should be completed to further improve melt rate. No analysis has been completed to determine if Frit 320 can be used in processing of other sludge macrobatches. The testing in this report is based on dried-slurry testing of a MB3 melter feed prepared from nonradioactive simulants. Additional testing, particularly with a melter feed slurry and actual waste, would be required before implementing the new frit in DWPF, and a variability study would also be necessary. The work to date, at most, provides relative data until actual melter data can be obtained and compared.

The testing details are collected in the individual reports and lab notebooks. The FY01 program had the following primary objectives in trying to improve the melt rate for MB3 in DWPF:

1. Develop alternate frit compositions.

2. Improve the protocol for melt-rate furnace testing to allow relative melt-rate comparisons.

3. Complete the crucible testing of various melter feeds to provide insight into their melting behavior and to screen out candidates exhibiting potential foam and/or batch expansion, which the melt rate team assumes will impede the melt rate.

4. Complete melt-rate furnace testing of the high-ranking melter feeds (from the crucible tests) to evaluate the melt rate of various frit and processing changes. Use data obtained from this testing to screen out poorer performing process options.

5. Repeat melt-rate tests with the best candidates, along with Frit 200 and Frit 165.

6. Evaluate property-composition relationships using various models and perform limited experimental testing (in particular durability) to confirm model predictions.

7. Make a recommendation to DWPF (based on data already collected) that will improve the melt rate for MB3.

The melt rate team recommends that DWPF switch to Frit 320 for MB3. Measured melt rates of Frit 320 were $40 \%$ faster than the nominal MB3 melter feed (Frit 200 based). Frit 320 produced a durable glass (all normalized elemental releases $<2 \mathrm{~g} / \mathrm{L}$ ) at a $25.5 \mathrm{wt} \%$ sludge oxide loading as measured by both quenched and centerline-cooled PCTs with both 
nominal and underwashed MB3 sludge. The current PCCS durability model accurately predicts the durability of this glass. Based on model predictions, the operational window in terms of waste loadings is essentially the same for both Frit 320 and Frit 200. The use of Frit 320 to improve the melt rate does not negatively impact waste loading. A variability study will be necessary before switching to Frit 320 to verify that the durability model is applicable over the compositional region with this frit (the composition of Frit 320 is summarized in Table 1). Additional testing, particularly with a melter feed slurry and actual waste, will also be required before implementing Frit 320 in DWPF for MB3.

Frit 304, a higher alkali (sodium and lithium), lower silica frit relative to Frit 320, should also increase the melt rate for MB3 in DWPF. Frit 304 melted the fastest of all the frits tested in crucible and melt-rate furnace testing with dried melter feeds at a fixed loading. This frit melted 51\% faster in melt-rate furnace testing than the nominal MB3 melter feed with Frit 200. The durability (as defined by the Product Consistency Test [PCT]) of quenched and centerline-canister-cooled glasses produced with Frit 304 as well as both the nominal and underwashed MB3 sludge at $25.5 \mathrm{wt} \%$ loading was also evaluated. All reportable normalized elemental releases were less than $2 \mathrm{~g} / \mathrm{L}$.

However, the current Product Composition and Control System (PCCS) durability model does not accurately predict the durability of this glass. The composition for this glass is outside the range of composition from which the parameters of the current durability model were estimated $^{1}$. As a result, the current DWPF melter-feed acceptance criterion (e.g., $\Delta \mathrm{G}_{\mathrm{P}}$ ) for durability would reject this glass. Therefore, a new or improved durability model is necessary before Frit 304 could be implemented. Because it is not likely that an improved durability model will be developed in time to support the initial MB3 sludge processing, Frit 304 is not recommended. Before introducing this change, a variability study would be necessary to (1) ensure that the glasses produced at various waste loadings (25-30 wt\% sludge oxides in glass) would be durable and (2) account for anticipated compositional variation in the MB3 sludge. The compositions of Frit 200 and Frit 304 are summarized in Table 1.

The melt rate team recommends that slurry feed testing be completed before switching to a new frit in DWPF. A new slurry-fed melt-rate furnace has been designed and built and could be used to ensure that the results of the dried-melter-feed testing applies to a melterfeed slurry. It is recommended that the slurry be tested in the 786-A minimelter, the largest SRTC slurry-fed melter available for testing. This minimelter was designed for DWPF testing and would enable the most prototypic slurry testing currently possible. These tests would lower the risks that the melt rate measured by the smaller scale, dry-feed tests would not directly relate to a larger, slurry-fed system. The melt rate team recommends that both the Frit 200 baseline and Frit 320 be tested in the SRTC shielded cells with actual radioactive MB3 waste to confirm that a durable glass can be produced using these frits (current plans only call for testing with Frit 200).

The impact of sludge washing and other processing changes was also assessed in terms of melt rate. The degree of sludge washing was varied because there is considerable interest in limiting sludge washing to minimize the generation of HLW water that must later be evaporated. The basis for the underwashed sludge was one less wash cycle than is currently 
WSRC-TR-2001-00148

planned. The underwashed sludge melted 19\% faster than the nominal MB3 melter feed (both using Frit 200), presumably because of the higher sodium content in the sludge. A strong general trend is that higher alkali leads to higher melt rates over the compositional region tested. Therefore, the challenge was to find a balance between enhanced melt rate and durability (and other properties) as a function of total alkali. The melt rate for MB3 was not significantly impacted either by adding sugar in the Slurry Mix Evaporator (SME) cycle or by adding formic acid as the only acid in the Sludge Receipt and Adjustment Tank (SRAT) cycle. A number of technical issues must be resolved prior to intentionally underwashing, as listed on page 16.

Table 1 - Nominal and Recommended Frit Oxide Target, wt \%

\begin{tabular}{|c|r|r|r|r||}
\hline \hline Frit oxide & Frit 165 & $\begin{array}{l}\text { Nominal } \\
\text { Frit 200 }\end{array}$ & Frit 304 & Frit 320 \\
\hline \hline $\mathrm{Al}_{2} \mathrm{O}_{3}$ & 0 & 0 & 2.3 & 0 \\
\hline $\mathrm{B}_{2} \mathrm{O}_{3}$ & 10 & 12 & 6.7 & 8 \\
\hline $\mathrm{SiO}_{2}$ & 68 & 70 & 67.1 & 72 \\
\hline $\mathrm{MgO}$ & 1 & 2 & 0.0 & 0 \\
\hline $\mathrm{Li}_{2} \mathrm{O}$ & 7 & 5 & 5.8 & 8 \\
\hline $\mathrm{Na}_{2} \mathrm{O}$ & 13 & 11 & 18.1 & 12 \\
\hline $\mathrm{ZrO}_{2}$ & 1 & 0 & 0.0 & 0 \\
\hline Total & 100 & 100 & 100.0 & 100 \\
\hline Sum of Alkali & 20 & 16 & 23.9 & 20 \\
\hline \multicolumn{5}{ll}{} \\
\hline \multicolumn{5}{|l}{}
\end{tabular}

\section{RECOMMENDATIONS}

The following is a list of the recommendations to improve the melt rate for MB3:

1. Replace Frit 200 with Frit 320 for MB3. Test the new frit in the 786-A minimelter, slurry-fed melt-rate furnace (if melt rate is measured in the minimelter test, the slurry fed melt rate test is not needed) and in the shielded cells demonstration that is planned.

2. Augment the variability study for MB3 glass to include regions that include Frit 320 .

3. Determine whether the process frit slurry has a potential for gel formation or leaching in DWPF processing and HLW recycle. Also compare the rheology of melter feed prepared with Frit 200 to melter feed prepared with Frit 320. The melter feed should be prepared using typical DWPF SRAT and SME processing.

4. Prepare the melter feed (using Frit 320) in the Glass Feed Prep System in 786-A and feed this product to the 786-A minimelter. Qualitatively assess the impact of this frit change on the melt rate. Consider measuring the corrosion rate of K-3 refractory and Inconel 690 corrosion coupons in melter runs with Frit 200 and Frit 320. 
WSRC-TR-2001-00148

5. Consider performing a study to determine whether Frit 320, possibly a softer frit, will impact the decontamination of the DWPF canisters.

6. Assess the applicability of the current liquidus temperature $\left(\mathrm{T}_{\mathrm{L}}\right)$ model over the projected composition region (i.e., ensure that spinel is the primary $\mathrm{T}_{\mathrm{L}}$ phase).

\section{FUTURE WORK}

The following is a list of the future work that is recommended to improve the melt rate but is not necessary to switch to Frit 320 in DWPF:

1. Initiate research to address the SME acceptability issues restricting the recommendation of Frit 304 for MB3. Issues that should be addressed include developing an alternative durability model (or enhancement of the existing model) that could be implemented into DWPF to supplant the current model. Based on the limited assessment, improving the durability model is not necessary to implement Frit 320.

2. Complete slurry-fed melt-rate testing of at least three frits, including Frits 320, 165 and 200 and compare the results from dried melt-rate furnace testing.

3. Initiate study of the effect of reduced washing on processing issues such as hydrogen generation, corrosion rate in melter offgas system, melt rate, DWPF processing time, and offgas generation in melter.

4. Initiate study on effect of reduced washing on halide and sulfate concentration and sodium variability.

5. Initiate a study to determine if the increased sodium in the sludge or frit has a larger impact on melt rate. 


\section{ACRONYMS}

$\begin{array}{ll}\text { DOE } & \text { U.S. Department of Energy } \\ \text { DWPF } & \text { Defense Waste Processing Facility } \\ \text { EA } & \text { Environmental Assessment } \\ \text { MB2 } & \text { Macrobatch 2 } \\ \text { MB3 } & \text { Macrobatch 3 } \\ \text { PAR } & \text { Property Acceptance Region } \\ \text { PCCS } & \text { Product Composition Control System } \\ \text { PCT } & \text { Product Consistency Test } \\ \text { PNNL } & \text { Pacific Northwest National Laboratory } \\ \text { SME } & \text { Slurry Mix Evaporator } \\ \text { SRAT } & \text { Sludge Receipt and Adjustment Tank } \\ \text { SRTC } & \text { Savannah River Technology Center } \\ \text { TFA } & \text { Tanks Focus Area }\end{array}$


WSRC-TR-2001-00148

This page intentionally left blank.

xiv 


\section{INTRODUCTION}

A study ${ }^{2}$ was completed in FY00 to identify processing and frit changes that would improve the melting rate of the glass in the Defense Waste Processing Facility (DWPF) melter, specifically for Macrobatch 2 (Sludge batch 1B). The FY00 testing demonstrated that the melt rate can be improved by using a different frit or by producing a much more reducing glass by adding sugar as a reductant (however, this more reducing glass was outside the "acceptable" redox limits). The frit that melted the fastest in the FY00 melt-rate testing was Frit 165 (only existing or previously developed frit compositions were tested during this study).

This report summarizes the data collected during the high-priority FY01 Macrobatch 3 (MB3) melt-rate testing for DWPF. Recommendations for alternative frit and/or chemical processing changes are provided to improve the melt rate for MB3 as well as supplemental tests (e.g., minimelter tests and the shielded cells demonstration) that should be performed before implementing the change in DWPF. Since the funding for the melt-rate task has been virtually consumed, the lower priority tasks (as identified in the Task Technical and QA Plan ${ }^{3}$ ) have not been completed at this time. This report also provides a recommendation to test a second frit (in addition to the Frit 200 baseline) in the Savannah River Technology Center (SRTC) shielded cells with actual radioactive MB3 before implementing a frit change for MB3 in DWPF.

The canister production rate needs to be increased in the DWPF. The goal of this study is to improve the melt rate in DWPF, specifically for MB3. However, the knowledge gained may result in improved melting efficiencies that could translate into future DWPF macrobatches and in higher throughput for other U.S. Department of Energy (DOE) melters. Increased melting efficiencies decrease overall operational costs by reducing the immobilization campaign time for a particular waste stream. For systems limited by the melt rate, a small increase in melting efficiency translates into significant savings by reducing life-cycle operational costs. Assuming that the DWPF is melt-rate limited and has a fixed annual operating cost of approximately $\$ 140$ million per year, every $1 \%$ increase in throughput as a result of increased melting efficiency would save an estimated $\$ 42$ million over the scheduled mission for high-level waste vitrification.

\section{FY 01 Study}

DWPF requested that SRTC complete a new study ${ }^{3}$ for MB3 (Sludge batch 2), the next sludge batch that will be processed by DWPF. This task, which is more extensive than the Macrobatch 2 study, requested that SRTC develop new frits and evaluate alternative chemical processing changes to improve the melt rate ${ }^{4}$. This report summarizes the results of this study and the recommendations that are necessary for DWPF to implement changes to improve the melt rate. 
WSRC-TR-2001-00148

Page 2 of 25

Individual reports have been written on the following topics, and this report uses the data and findings of each of these reports to make the final recommendations to DWPF. The individual reports are listed in Table 1.

Table 1 - Reports Used as Sources for the Present Report

\begin{tabular}{|c|c|c|}
\hline Document Number & Authors & $\begin{array}{ll}\text { Title } \\
\end{array}$ \\
\hline 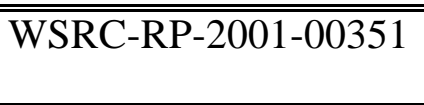 & $\begin{array}{l}\text { D.K. Peeler, T.H. } \\
\text { Lorier, J.D. Vienna }\end{array}$ & $\begin{array}{l}\text { Foaming Theory and Mitigation } \\
\text { Techniques }\end{array}$ \\
\hline WSRC-TR-2001-00131 & $\begin{array}{l}\text { D.K. Peeler, T.B. } \\
\text { Edwards, T.H. Lorier, } \\
\text { K.G. Brown, D.F. } \\
\text { Bickford, I.A. Reamer, } \\
\text { J. D. Vienna, D.C. } \\
\text { Witt, R.J. Workman } \\
\end{array}$ & Frit Development and Model Assessment \\
\hline WSRC-TR-2001-00152 & T.H. Lorier & Frit Preparation \\
\hline WSRC-TR-2001-00126 & $\begin{array}{l}\text { M. E. Stone, } \\
\text { D. P. Lambert }\end{array}$ & Feed Preparation \\
\hline WSRC-TR-2001-00151 & T.H. Lorier & Crucible Studies \\
\hline WSRC-TR-2001-00146 & $\begin{array}{l}\text { M. E. Stone, } \\
\text { J. E. Josephs }\end{array}$ & Melt-Rate Furnace Testing \\
\hline WSRC-TR-2001-00158 & $\begin{array}{l}\text { M. E. Stone, } \\
\text { J. E. Josephs }\end{array}$ & Sugar Addition Test \\
\hline
\end{tabular}

\section{Recommended Processing for DWPF Macrobatch 3}

The DWPF flowsheet for MB3 (the MB3 sludge simulant is an equal blend of Tank 8 and Tank 40 on a weight basis $)^{5}$ has been tested extensively using simulated sludge. The chemical processing is similar to that for Macrobatch 2 in that it uses a combination of nitric acid and formic acid during the melter-feed preparation to produce a melter feed with a predicted $\mathrm{Fe}^{+2} / \Sigma \mathrm{Fe}$ ratio of approximately 0.20 . Frit 200 was used as the glass former. The MB3 melt-rate study focuses on two changes to improve melt rate: (1) changes in frit composition and (2) changes to the feed-preparation process to alter the redox of the melter feed. These two factors were investigated for MB3 (Sludge batch 2) using crucible studies and a specially designed "melt rate" furnace. Other potential factors that could increase melt rate, which are being investigated by separate programs, include (1) mechanical mixing via stirring or the use of bubblers, (2) changing the power skewing to redistribute the power input to the melter, and (3) eliminating heat loss (e.g., air inleakage).

\section{Limitations of Testing}

The conclusions and recommendations made in this report are based on tests completed with dried, nonradioactive MB3 melter-feed simulants in small-scale testing at a fixed waste loading. The results from these small-scale tests should provide a relative measure of melt rate among different feed compositions, but may not provide a direct link to full-scale radioactive processing 
WSRC-TR-2001-00148

Page 3 of 25

of melter-feed slurries. This melt-rate task did not evaluate the impact of a frit or processing change on a number of pre- or post-melter effects, such as feed rheology, evaporator issues, fritdecontamination issues, pour-spout issues, corrosion/erosion, etc. that are important to DWPF. These will need to be evaluated before any frit change is implemented.

\section{OVERVIEW OF SOURCE DOCUMENTS}

The melt-rate testing task was developed with the input of DWPF engineers, SRTC glass and waste-processing researchers, Pacific Northwest National Laboratory (PNNL) glass and melter experts, and Dr. Frank Woolley, retired Corning Melter Engineering Manager. First, a meeting was held with Dr. Pavel Hrma and Joe Perez of PNNL, DWPF engineers, and SRTC glass and processing researchers to help refine our understanding of the melt-rate issues being experienced in DWPF for Macrobatch 2 (MB2) and to solicit assistance from PNNL in supporting this meltrate task. Second, a meeting was held with Dr. Frank Woolley, DWPF engineers, and SRTC glass and processing researchers to help define the goals of the testing and identify alternative approaches to improve the melt rate. The funding for the melt-rate task was a combination of DWPF support and Tanks Focus Area (TFA) funding. PNNL supported this task through their assistance in developing new frits ${ }^{6}$ and their literature survey of bubbler and reductant testing ${ }^{7}$ to improve melt rate.

The melt-rate testing was requested by a Task Technical Request ${ }^{2}$, and the high-priority tasks have been completed as defined in the Task Plan ${ }^{3}$. The lower priority tasks will be performed if additional funding becomes available.

The following discussion summarizes the key findings in the individual reports that were written as a result of this work. Details for each of these subjects can be found in the individual reports and lab notebooks.

\section{Incentive, Foaming Theory, and Mitigation Techniques to Improve Melt Rate}

Document: WSRC-RP-2001-00351, Melt Rate Improvement For DWPF MB3: Foaming Theory and Mitigation Techniques, D. K. Peeler, T.H. Lorier, and J.D. Vienna, March 30, 2001.

This report was written to (1) provide the incentive for increasing the melt rate, (2) provide a technical basis of the fundamental mechanisms for foam and/or batch expansion and the potential impacts on melt rate, and (3) identify techniques to minimize foam formation and/or batch expansion in DWPF. The report states

Glass melting is a complex process that involves a number of reactions and transformations. Consequently, it is necessary to identify the relevant processes for cold cap melting and possible laboratory test methods to evaluate these pertinent processing properties. It has been suggested that the development of appropriate laboratory test methods to assess melt rate should be preceded by an understanding of the basic processes involved in cold cap melting. The effects of various melter operating conditions and physical/chemical properties of the feed on the melting rate need to be clearly established. Because of the complexities involved, several analytical techniques should be used to characterize the local processes 
WSRC-TR-2001-00148

Page 4 of 25

leading from batch to homogeneous glass and to link the bulk melt to the reaction at the interfaces.

This report also defines the objective for this task to be as follows:

To enhance the basic understanding of the role of glass batch chemistry (more specifically via control of frit composition) and/or changes in chemical processing strategies on the overall melting process for MB3 (DWPF sludge-only processing). Through control of batch chemistry, cold cap reactions can be altered which may result in higher melter throughput. For melt rate limited systems, a small increase in melting efficiency translates into substantial savings by reducing operational costs without compromising the quality of the final waste form or product.

\section{Develop Alternate Frit Compositions}

Document: WSRC-TR-2001-00131, Melt Rate Improvement For DWPF MB3: Frit Development and Model Assessment, D. K. Peeler et al., March 30, 2001.

Stone and Lambert ${ }^{1}$ demonstrated that melt rate could be improved by changing the composition of the frit for MB2. Frit 165 led to a significant increase in melt rate compared to identical runs with Frit 200 (see Table 2 to compare compositions). DWPF Frits 131 and 202 were also tested and all had distinctly different compositions and measured melt rates.

As was discussed in the report titled Foaming Theory and Mitigation Techniques to Improve Melt Rate (see Table 1), modifying the frit composition may minimize foam formation and/or batch expansion, leading to higher throughputs or melt rates. Compositional changes to the frit alter the reaction pathways during the batch-to-glass conversion process. A number of suggestions were made to improve the melt rate, including two component frits, high alkali frit, refractory (high-melting point) frit, glass-forming chemicals instead of frit, and changes to the frit particle size. These suggestions were incorporated into the planning ${ }^{3}$ to develop alternative frits.

Frit-development activities were a joint SRTC/PNNL effort. The overall strategy for these activities was to explore frit compositional regions (both in terms of oxide components and ranges) that challenged "acceptable" predicted property behavior and were thought to increase the melt rate. The frits were developed using the following frit components: aluminum oxide $\left(\mathrm{Al}_{2} \mathrm{O}_{3}\right)$, boron oxide $\left(\mathrm{B}_{2} \mathrm{O}_{3}\right)$, silicon dioxide $\left(\mathrm{SiO}_{2}\right)$, magnesium oxide $(\mathrm{MgO})$, lithium oxide $(\mathrm{Li} 2 \mathrm{O})$, sodium oxide $\left(\mathrm{Na}_{2} \mathrm{O}\right)$, and zirconium oxide $\left(\mathrm{ZrO}_{2}\right)$. Most of the frits are four-component mixtures which did not contain aluminum oxide, zirconium oxide, or magnesium oxide. To cover the full compositional space, a wide variation was made in the composition of the alternative frits.

SRTC and PNNL recommended a total of 28 frit compositions, included 25 new frits (see Table 2). 
Table 2 - Compositions (mass percent) of Existing Frits and Additional Recommended Frits

\begin{tabular}{|c|c|c|c|c|c|c|c|c|c|c|c|c|c|c|}
\hline Oxide & $\begin{array}{c}\text { Frit } \\
202^{(\mathbf{a})}\end{array}$ & $\begin{array}{c}\text { Frit } \\
\text { 200 }^{(\text {a) }}\end{array}$ & $\begin{array}{c}\text { Frit } \\
165^{(\mathbf{a})}\end{array}$ & \begin{tabular}{|c|} 
Frit \\
165 \\
Without \\
$\mathrm{ZrO}_{2}$
\end{tabular} & $\mid \begin{array}{c}\text { Frit } \\
302^{(c)}\end{array}$ & $\begin{array}{l}\text { Frit } \\
303\end{array}$ & $\begin{array}{l}\text { Frit } \\
304\end{array}$ & $\begin{array}{l}\text { Frit } \\
305\end{array}$ & $\begin{array}{l}\text { Frit } \\
306\end{array}$ & $\begin{array}{l}\text { Frit } \\
\mathbf{3 0 7}\end{array}$ & $\begin{array}{l}\text { Frit } \\
308\end{array}$ & $\begin{array}{l}\text { Frit } \\
309\end{array}$ & $\begin{array}{l}\text { Frit } \\
310\end{array}$ & $\begin{array}{c}\text { Frit } \\
\text { 311 }^{(d)}\end{array}$ \\
\hline $\mathrm{Al}_{2} \mathrm{O}_{3}$ & 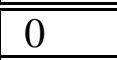 & 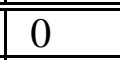 & 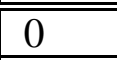 & 0.00 & 2.3 & 2.3 & 2.3 & 0.0 & $\begin{array}{c}0.0 \\
\end{array}$ & 0.0 & 2.3 & $\begin{array}{c}0.0 \\
\end{array}$ & $\begin{array}{l}1.1 \\
\end{array}$ & $\begin{array}{l}1.1 \\
\end{array}$ \\
\hline $\mathrm{B}_{2} \mathrm{O}_{3}$ & 8 & 12 & 10 & 10.1 & 20.1 & 20.1 & 6.7 & 6.7 & 12.1 & 12.1 & 6.7 & 8.1 & 12.0 & 12.0 \\
\hline $\mathrm{Li}_{2} \mathrm{O}$ & 7 & 5 & 7 & 7.1 & 5.2 & 10.1 & 5.8 & 10.7 & 7.2 & 10.7 & 5.8 & 7.9 & 6.3 & 10.7 \\
\hline $\mathrm{Na}_{2} \mathrm{O}$ & 6 & 11 & 13 & \begin{tabular}{|l|}
13.1 \\
\end{tabular} & 8.3 & 0.0 & 18.1 & 6.9 & 10.2 & 4.7 & 18.1 & 12.0 & 12.5 & 4.8 \\
\hline $\mathrm{SiO}_{2}$ & 77 & 70 & 68 & 68.7 & 64.1 & 67.5 & 67.1 & 75.6 & 70.5 & 72.5 & 67.1 & 72.0 & 68.1 & 71.3 \\
\hline $\mathrm{ZrO}_{2}$ & 0 & 0 & 1 & 0.0 & 0.0 & 0.0 & 0.0 & 0.0 & 0.0 & 0.0 & 0.0 & 0.0 & 0.0 & 0.0 \\
\hline $\mathrm{MgO}$ & 2 & 2 & 1 & 1.0 & 0.0 & 0.0 & 0.0 & 0.0 & 0.0 & 0.0 & 0.0 & 0.0 & 0.0 & 0.0 \\
\hline Oxide & $\begin{array}{l}\text { Frit } \\
\mathbf{3 1 2}\end{array}$ & $\begin{array}{l}\text { Frit } \\
313 \\
\end{array}$ & $\begin{array}{l}\text { Frit } \\
314 \\
\end{array}$ & $\begin{array}{l}\text { Frit } \\
315\end{array}$ & $\begin{array}{l}\text { Frit } \\
\mathbf{3 1 6}\end{array}$ & $\begin{array}{l}\text { Frit } \\
\mathbf{3 1 7}\end{array}$ & $\begin{array}{l}\text { Frit } \\
318\end{array}$ & $\begin{array}{l}\text { Frit } \\
319 \\
\end{array}$ & $\begin{array}{l}\text { Frit } \\
320\end{array}$ & $\begin{array}{l}\text { Frit } \\
322\end{array}$ & $\begin{array}{l}\text { Frit } \\
323\end{array}$ & $\begin{array}{l}\text { Frit } \\
\mathbf{3 2 4}\end{array}$ & $\begin{array}{c}\text { Frit } \\
325^{(b)}\end{array}$ & $\begin{array}{l}\text { Frit } \\
326 \\
\end{array}$ \\
\hline $\mathrm{Al}_{2} \mathrm{O}_{3}$ & 0.0 & 0.0 & 0.0 & 0.0 & 0.0 & 0.0 & $\begin{array}{l}1.1 \\
\end{array}$ & 1.1 & 0.0 & 0.0 & 0.0 & 0.0 & 0 & 0.0 \\
\hline $\mathrm{B}_{2} \mathrm{O}_{3}$ & 6.7 & 6.7 & 20.1 & 20.1 & 12.0 & 12.0 & 12.0 & 12.0 & 8.0 & 8.0 & 20.0 & 15.0 & 8.55 & 8.0 \\
\hline $\mathrm{Li}_{2} \mathrm{O}$ & 6.9 & 10.7 & 5.9 & 10.0 & 10.7 & 6.8 & 5.9 & 10.7 & 8.0 & 5.0 & 10.0 & 8.3 & 7.55 & 8.0 \\
\hline $\mathrm{Na}_{2} \mathrm{O}$ & 15.2 & 8.8 & 6.1 & 0.0 & 3.1 & 11.1 & 13.3 & 4.7 & 12.0 & 10.0 & 10.0 & 5.2 & 9.1 & 11.0 \\
\hline $\mathrm{SiO}_{2}$ & 69.2 & 73.8 & 65.8 & 69.8 & 73.2 & 69.1 & 66.7 & 70.4 & 72.0 & 77.0 & 70.0 & 71.5 & 72.8 & 72.0 \\
\hline $\mathrm{ZrO}_{2}$ & 2.0 & 0.0 & 2.0 & 0.0 & 1.0 & 1.0 & 1.0 & \begin{tabular}{|l|}
1.0 \\
\end{tabular} & 0.0 & 0.0 & 0.0 & 0.0 & 0 & 0.0 \\
\hline $\mathrm{MgO}$ & 0.0 & 0.0 & 0.0 & 0.0 & 0.0 & 0.0 & 0.0 & 0.0 & 0.0 & 0.0 & 0.0 & 0.0 & 1.5 & 1.0 \\
\hline
\end{tabular}

(a) Existing frits.

(b) Frit developed to couple with Frit 202. The composition in the table is a 50/50 combination of both frit components.

(c) All frits in the 300 series were developed as part of this study.

(d) It should be noted that Frit 311 as defined in Table 2, does not correspond to the Frit 311 developed by Jantzen $(1998)^{8}$. 
WSRC-TR-2001-00148

Page 6 of 25

\section{Preparation of Frits for Crucible and Melt-Rate Furnace Testing.}

Document: WSRC-TR-2001-00126, Melt Rate Improvement For DWPF MB3: Frit Preparation, M. E. Stone et al., March 30, 2001.

A report was written to document the preparation of the frits that were used in crucible and meltrate furnace testing. Three of the frits were already available, Frits 165 (Lot \# AX667974), 200 (Lot \# CS), and 202 (Lot \# CN). The remainder of the frits were prepared by SRTC to produce a frit particle-size range between 200 mesh $(74 \mu \mathrm{m})$ and 80 mesh $(177 \mu \mathrm{m})$. This particle-size range was necessary to ensure consistency when comparing different frit compositions, knowing that that differences in particle size between frits can influence melt behavior and melt rate. In addition, two batches of glass formers were prepared equivalent to Frits 200 and 165.

Twelve initial frit batches were produced to support the crucible and initial melt-rate furnace tests. Six of the twelve initial frits were chosen for retesting in the melt-rate furnace. Since the initial frits had been consumed in crucible and melt-rate furnace testing, a second batch of each of the six recommended frits was produced.

All the frits were analyzed after size reduction to ensure that the final (measured) frit composition met targeted values. Potential sources of compositional differences include (1) batching errors, (2) potential volatility (in particular, alkali and boron), and (3) contamination from the grinding process. Note that all the frits were contaminated by iron, chromium, and nickel as a result of the wear of the grinding equipment. As much of the magnetic iron was removed as feasible. Sample results demonstrate that the frits were made as planned with a small amount $(<0.25 \mathrm{wt} \%)$ of iron impurity present.

\section{Development of Melter Feeds for Melt-Rate Furnace Testing}

Document: WSRC-TR-2001-00126, Melt Rate Improvement For DWPF MB3: Feed Preparation, M. E. Stone et al., March 30, 2001.

A report was written to document the preparation of the melter feeds that were used in crucible and melt-rate furnace testing. The MB3 sludge is a 50-volume \% mixture of Tank 8 and Tank 40 sludge. Based on analyses of these radioactive sludge tanks, Elder predicted the composition of both the Tank 8 and Tank 40 sludges after washing ${ }^{9}$. Sludge simulants were prepared at the University of South Carolina to supply the sludge necessary for this testing. The MB3 sludge simulant used for all melt-rate testing is an equal blend of Tank 8 and Tank 40 sludge simulants on a weight basis.

Approximately 60 L of nominal MB3 Sludge Receipt and Adjustment Tank (SRAT) product were prepared. The SRAT product was prepared by processing the sludge simulant through a typical DWPF SRAT cycle. A typical DWPF SRAT cycle consists of adding nitric acid and formic acid to the sludge at $93^{\circ} \mathrm{C}$ followed by approximately $12 \mathrm{~h}$ at boiling. This nominal MB3 SRAT product was combined with frit to produce a melter-feed slurry. This is different than the normal DWPF processing since in DWPF, the frit is added as a frit/water slurry, requiring significant time at boiling to remove the water added with the frit. However, this is not expected to significantly impact the slurry composition or impact the melt rate assessment. Since testing 
WSRC-TR-2001-00148

Page 7 of 25

used a dried melter feed, the Slurry Mix Evaporator (SME) cycle was not simulated during this testing. All melter feed slurries were dried, and the size was reduced before use.

In addition to preparing the nominal SRAT product, three processing changes were investigated: reducing (formic acid only), underwashed, and overwashed. The reducing SRAT product was produced with formic acid only (no nitric acid) during the SRAT cycle. The underwashed SRAT product was produced by adding the soluble sodium salts removed during sludge washing to the simulated sludge to represent one less wash during sludge pretreatment. The overwashed sludge had an additional wash performed on the simulated sludge to reduce the sodium content by half. The melter feed was prepared by combining the alternative SRAT products with Frit 200. This melter-feed slurry was dried and size reduced before being used. The amount of nitric acid and formic acid added was calculated to target a redox (measure of reduction/oxidation potential) of $0.2 \mathrm{Fe}+2 / \Sigma \mathrm{Fe}^{10}$ for the nominal, underwashed, and overwashed SRAT products.

\section{Complete Crucible Testing of Various Melter Feeds to Understand Melting Behavior and Screen Out Poor Candidates}

Document: WSRC-TR-2001-00151, Melt Rate Improvement for DWPF MB3: Crucible Studies, T. H. Lorier, March 30, 2001.

A report was written to summarize the isothermal crucible studies completed to provide a fundamental understanding of the melting behavior of various frit/sludge mixtures. The purpose of this testing was to provide a general understanding of the batch-to-glass conversion process: the reaction pathways, foaming and/or batch expansion potential, and melting behavior. The crucible testing used was similar to time-temperature-transformation testing that is routinely performed to support glass studies. To simplify this testing, all the isothermal tests lasted $2 \mathrm{~h}$ as FY00 testing demonstrated that little additional information was obtained by holding the crucibles at temperature for longer time periods. This testing was completed by combining MB3 SRAT product slurry with frit in a $125-\mathrm{mL}$ alumina crucible and drying the contents to $<75 \mathrm{~g}$ (crucibles are batched to produce $45 \mathrm{~g}$ of glass). After drying, the crucibles were inserted into an isothermal muffle furnace and held for $2 \mathrm{~h}$ before air quenching. After cooling, the crucibles were weighed, sectioned, and photographed. The most important information extracted from this testing is the visual observations (which are essential in understanding the melting behavior) of the reacted batch.

Over 175 crucible tests were conducted as part of this study. Figure 1 compares the reaction pathways or general melt behavior of MB3 SRAT Product with Frit 200 (left column) and Frit 304 (right column). These clearly show that the Frit 304 melter feed begins to react and melt much earlier than the Frit 200 melter feed. The batch expansion occurs at a much lower temperature in the run with Frit 304 (maximum foam $700^{\circ} \mathrm{C}$ ). It also formed bubble-free glass at a lower temperature. Although the limitations of this test (isothermal, non-uni-directional heat flux) are recognized, these features are strong indications that Frit 304 will melt faster than Frit 200. This testing also shows that foaming is not so excessive that the batch cannot be contained in the crucible. 
WSRC-TR-2001-00148

Page 8 of 25

Frit 200

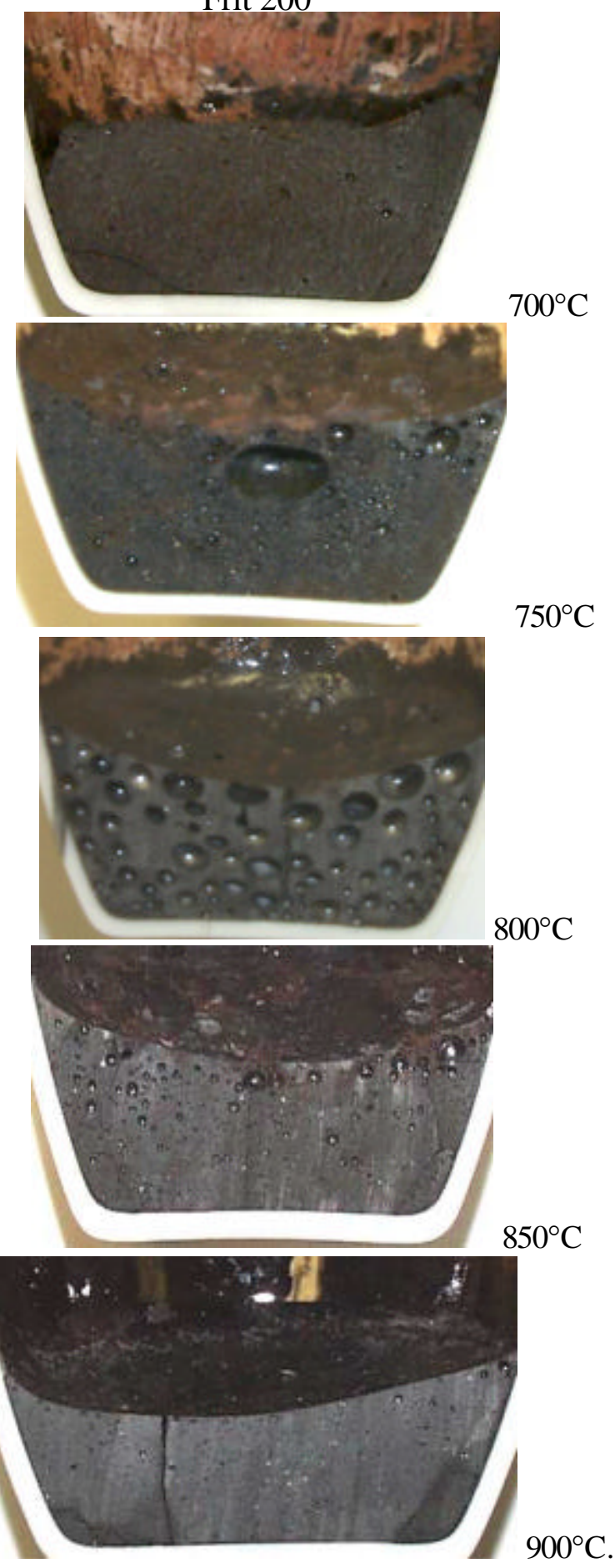

Frit 304

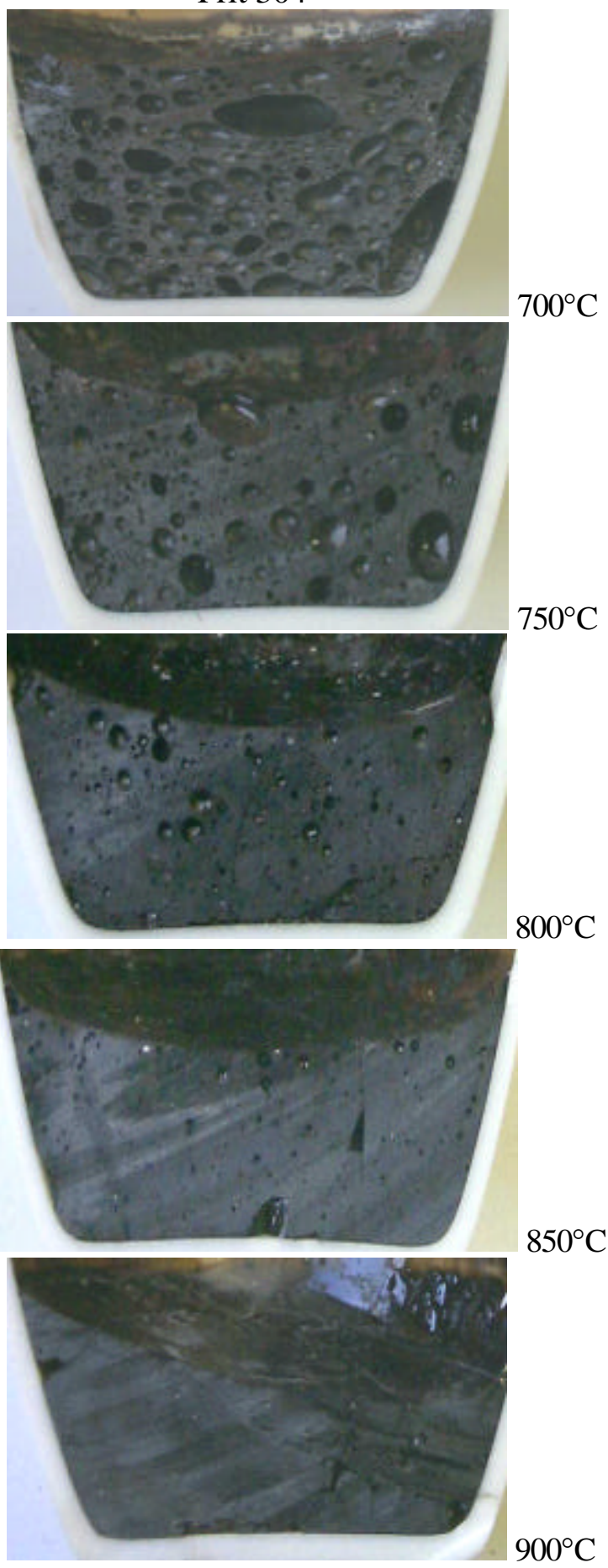

Figure 1 - Comparison of Sectioned Crucibles of Frit 200 and 304 
The crucible tests were effective in providing a basic understanding of the melting behavior of MB3 glasses. The testing shows that there are potential foaming and/or batch expansion issues with MB3, but this can be controlled through the choice of an appropriate frit. Based on these tests, Frits 165, 304, 307, and 320 appear to melt faster than the other frits tested (including the Frit 200 baseline). However, due to the limitations of these tests (e.g., small scale and isothermal temperatures), testing was also completed in the melt-rate furnace to confirm these results.

The data generated during the crucible testing and product composition and control system (PCCS) modeling were combined with guidance from Bickford and Jantzen to down-select from 25 frits to 12 frits as summarized in Table 3.

Table 3 - Frit Oxide Composition of Twelve Recommended Frits (First Cut)

\begin{tabular}{||l|c|c|c|c|c|c|c|c|c|c|c|c||}
\hline \hline Oxide & $\begin{array}{c}\text { Frit } \\
\mathbf{3 0 3}\end{array}$ & $\begin{array}{c}\text { Frit } \\
\mathbf{3 0 4}\end{array}$ & $\begin{array}{c}\text { Frit } \\
\mathbf{3 0 7}\end{array}$ & $\begin{array}{c}\text { Frit } \\
\mathbf{3 1 3}\end{array}$ & $\begin{array}{c}\text { Frit } \\
\mathbf{3 1 4}\end{array}$ & $\begin{array}{c}\text { Frit } \\
\mathbf{3 1 5}\end{array}$ & $\begin{array}{c}\text { Frit } \\
\mathbf{3 2 0}\end{array}$ & $\begin{array}{c}\text { Frit } \\
\mathbf{3 2 2}\end{array}$ & $\begin{array}{c}\text { Frit } \\
\mathbf{3 2 3}\end{array}$ & $\begin{array}{c}\text { Frit } \\
\mathbf{3 2 4}\end{array}$ & $\begin{array}{c}\text { Frit } \\
\mathbf{3 2 5}\end{array}$ & $\begin{array}{c}\text { Frit } \\
\mathbf{3 2 6}\end{array}$ \\
\hline \hline $\mathrm{B}_{2} \mathrm{O}_{3}$ & 20.1 & 6.7 & 12.1 & 6.7 & 20.1 & 20.1 & 8.0 & 8.0 & 15.0 & 15.0 & 8.6 & 8.0 \\
\hline $\mathrm{Li}_{2} \mathrm{O}$ & 10.1 & 5.8 & 10.7 & 10.7 & 5.9 & 10.0 & 8.0 & 5.0 & 5.2 & 8.3 & 7.6 & 8.0 \\
\hline $\mathrm{Na}_{2} \mathrm{O}$ & 0.0 & 18.1 & 4.7 & 8.8 & 6.1 & 0.0 & 12.0 & 10.0 & 8.3 & 5.2 & 9.1 & 11.0 \\
\hline $\mathrm{SiO}_{2}$ & 67.5 & 67.1 & 72.5 & 73.8 & 65.8 & 69.8 & 72.0 & 77.0 & 71.5 & 71.5 & 72.8 & 72.0 \\
\hline $\mathrm{Al}_{2} \mathrm{O}_{3}$ & 2.3 & 2.3 & 0.0 & 0.0 & 0.0 & 0.0 & 0.0 & 0.0 & 0.0 & 0.0 & 0.0 & 0.0 \\
\hline $\mathrm{MgO}$ & 0.0 & 0.0 & 0.0 & 0.0 & 0.0 & 0.0 & 0.0 & 0.0 & 0.0 & 0.0 & 1.5 & 1.0 \\
\hline $\mathrm{ZrO}_{2}$ & 0.0 & 0.0 & 0.0 & 0.0 & 2.0 & 0.0 & 0.0 & 0.0 & 0.0 & 0.0 & 0.5 & 0.0 \\
\hline
\end{tabular}

Note: existing Frits 165 and 200 along with Frit 165 without $\mathrm{ZrO} 2$ were also included in the testing

\section{Melt-Rate Furnace Testing}

Document: WSRC-TR-2001-00146, Melt Rate Improvement for DWPF MB3: Melt Rate

Furnace Testing, M. E. Stone, J. E. Josephs, March 30, 2001.

Document: WSRC-TR-2001-00158, Melt Rate Improvement for DWPF MB3: Sugar Addition

Test, J. E. Josephs, M. E. Stone, March 30, 2001.

A melt-rate furnace was used to assess the melt rate of various dried melter feeds. A 4-in. beaker (about $1 / 300^{\text {th }}$ of DWPF melter's cross-sectional area) with approximately 3 in. of dried melter feed was inserted into a melt-rate furnace held at approximately $1150^{\circ} \mathrm{C}$. Thermocouples in the batch and vapor space monitored the melting. At the conclusion of each run, the beaker was air quenched, cooled, and sectioned for observation.

A sectioned beaker from an experiment with nominal MB3 melter feed is shown in Figure 2. Note the large air voids and obvious bridging in this experiment. Some unmelted batch can be seen at the top of the beaker and melted glass at the bottom of the beaker. The method used to determine the melt rate was to measure the height of the glass pool formed during each test and divide by the run time, the same method used during MB2 testing ${ }^{1}$. The height of the glass pool 
was measured at the point where the glass had become free of bubbles. Measuring the melt rate by measuring the height of the glass formed is complicated by the irregularities in the height of the melt pool due to large bubbles present during many runs. To minimize the error caused by the irregularities in the height, each beaker was measured at 1/4-in. intervals across the beaker.

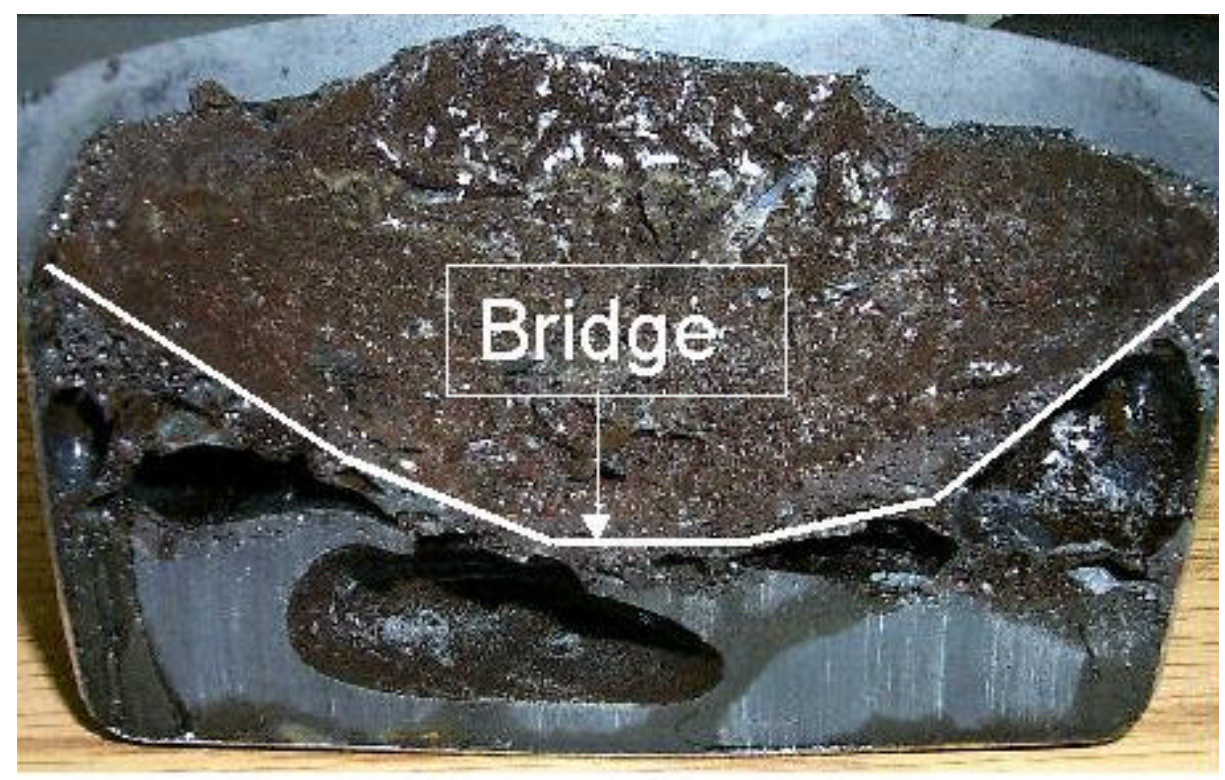

\section{Figure 2 - Sectioned Beaker from Nominal Macrobatch (Frit 200) Melt-Rate Furnace Test}

Two approaches were used to determine the glass height in the runs with irregular height profiles. The linear method involves measuring the batch height at 1/4-in. intervals across the beaker, then averaging the values to obtain an average glass pool height. The average glass pool height was divided by the run time to obtain the melt-rate result in inches per hour. The volumetric method involves calculating the volume of each concentric ring represented by the batch height at $1 / 4-$ in. intervals, then summing the volume of the rings to obtain the volume of glass produced during the run. The glass volume is then divided by the run time to obtain a melt rate in cubic inches per hour.

\section{Frit Changes}

The melt rate can be estimated by measuring the height of melted glass. The linear melt rate for the Frit 200, nominal MB3 feed was estimated to be 0.75 in. per hour in the melt-rate furnace.

To contrast with the Frit 200 baseline test (see Figure 2), a run using Frit 304 was made for the same 42-min time in the melt-rate furnace. A picture of the sectioned beaker is shown in Figure 3. Note that there is no obvious bridging, and most of the batch has been converted to glass. The linear melt rate is estimated to be 1.13 in. per hour in the melt-rate furnace, an estimated increase of $51 \%$ relative to the Frit 200 baseline.

Figure 3 - Sectioned Beaker from Frit 304 Run 
WSRC-TR-2001-00148

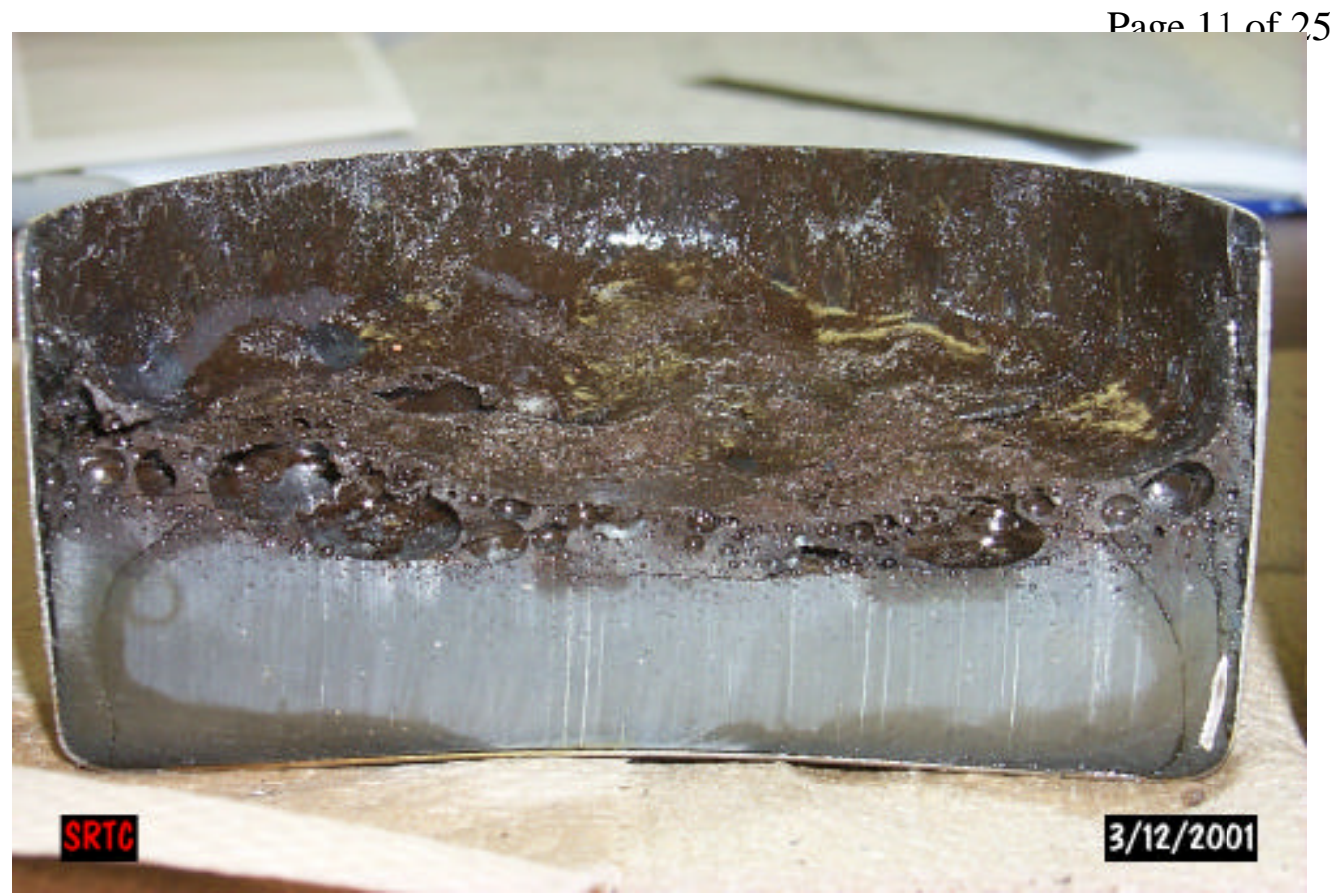

The melt-rate furnace test results (coupled with the isothermal crucible tests) were used to screen out the slower melting frits. As a result of this testing, Frits 304, 307, 313, 320, 323, 326, 165, and 200 were recommended for duplicate testing.

The calculated linear melt rate (inches per hour) and the calculated volumetric melt rate (cubic inches per hour) are summarized in Table 4. Based on the calculated melt rates, the melt-rate increase of each frit was estimated compared to the Frit 200 baseline. The following is the ranking by melt rate (from highest to lowest) of the down-selected frits, based on linear and volumetric melt-rate estimates in duplicate testing:

1. 304

2. 320

3. 313

4. $165,326,307$

5. 323

6. 200

Table 4 - Melt-Rate Estimate of Recommended Frits Based on Melt-Rate Furnace Tests

\begin{tabular}{|l|c|c|c|c|c|c|c|c||}
\hline Frit & $\mathbf{2 0 0}$ & $\mathbf{1 6 5}$ & $\mathbf{3 0 4}$ & $\mathbf{3 0 7}$ & $\mathbf{3 1 3}$ & $\mathbf{3 2 0}$ & $\mathbf{3 2 3}$ & $\mathbf{3 2 6}$ \\
\hline \hline Linear Melt Rate, inch/hour & 0.75 & 0.95 & 1.13 & 0.93 & 1.01 & 1.05 & 0.62 & 0.95 \\
\%Increase & & $27 \%$ & $51 \%$ & $24 \%$ & $35 \%$ & $40 \%$ & $-17 \%$ & $27 \%$ \\
\hline Volumetric Melt Rate, inch $^{3}$ hour & 11.0 & 12.9 & 15.1 & 12.6 & 13.8 & 14.0 & 9.1 & 13.0 \\
\%Increase & & $17 \%$ & $37 \%$ & $15 \%$ & $25 \%$ & $27 \%$ & $-17 \%$ & $18 \%$ \\
\hline
\end{tabular}

Based on this analysis, Frit 304 melted the fastest of all the tests. Frits 320 and 313 also melted significantly faster than Frit 200. Frits 165, 326, and 307 also melted significantly faster than Frit 200, but were slightly slower than Frits 304, 320, or 313. Frit 323 melted slower than the Frit 200 baseline. 
WSRC-TR-2001-00148

Page 12 of 25

After analysis of the melt rate data, an attempt was made to develop another new frit that had a high melt rate (similar to Frit 304) but with a predictable glass durability using the current PCCS model $^{11}$. Analysis of the melt-rate data indicates that higher alkali content (on a molar basis) correlates well with higher melt rate, as shown in Figure 4. Substitution of lithium for sodium on a weight percent basis increases the molar content of alkali in the glass while maintaining a constant alkali content in the glass on a weight-percent basis; therefore, the composition of Frit 320 was modified to increase the ratio of lithium to sodium, as shown in Table 5. The new frit, Frit 320-A was developed with approximately the same total alkali by mass but with more lithium and less sodium. Alumina was left out of Frit 320-A making it a four component frit. The silica and borate content in the frit were changed slightly to have integer quantities for all frit components on a weight basis. The melt rate for Frit 320-A was predicted to be higher than Frit 320 and slightly lower than Frit 304 based on the relationship between alkali content and melt rate, but the actual melt rate was comparable to Frit 320 .

Table 5 - Composition of Frits 320, 320-A and 304

\begin{tabular}{||l|c|c|c|c|c|c||}
\hline FRIT & \multicolumn{2}{|c|}{ Frit 320 } & \multicolumn{2}{c|}{ Frit 320-A } & \multicolumn{2}{c||}{ 304 } \\
\hline $\begin{array}{l}\text { Frit } \\
\text { Component }\end{array}$ & $\begin{array}{c}\text { Weight } \\
\text { Percent }\end{array}$ & $\begin{array}{c}\text { Mole } \\
\text { Percent }\end{array}$ & $\begin{array}{c}\text { Weight } \\
\text { Percent }\end{array}$ & $\begin{array}{c}\text { Mole } \\
\text { Percent }\end{array}$ & $\begin{array}{c}\text { Weight } \\
\text { Percent }\end{array}$ & $\begin{array}{c}\text { Mole } \\
\text { Percent }\end{array}$ \\
\hline \hline $\mathrm{Al}_{2} \mathrm{O}_{3}$ & 0.00 & 0.00 & 0.0 & 0.0 & 1.84 & 1.11 \\
\hline $\mathrm{B}_{2} \mathrm{O}_{3}$ & 8.14 & 6.91 & 8.0 & 6.56 & 6.96 & 6.15 \\
\hline $\mathrm{Li}_{2} \mathrm{O}$ & 7.75 & 15.34 & 11.0 & 21.06 & 5.65 & 11.67 \\
\hline $\mathrm{Na}_{2} \mathrm{O}$ & 11.98 & 11.40 & 9.0 & 8.28 & 17.2 & 17.07 \\
\hline $\mathrm{SiO}_{2}$ & 71.88 & 66.19 & 72.0 & 64.09 & 66.6 & 63.94 \\
\hline $\mathrm{\Sigma Alkali}$ & 19.73 & 26.74 & 20.0 & 29.34 & 22.85 & 28.74 \\
\hline $\begin{array}{l}\text { Melt Rate, } \\
\text { in/hour }\end{array}$ & \multicolumn{2}{|l|}{1.05 (measured) } & 1.11 (predicted) & \multicolumn{2}{|c||}{1.13 (measured) } \\
\hline \hline
\end{tabular}

Calculations using PCCS were performed for a nominal wash and underwashed sludge with Frit 320-A. As shown in Table 6, the predicted properties match very closely with Frit 320 and indicate that an acceptable operating window exists for this frit with both types of sludge. Predicted properties based on 25.5 wt \% sludge oxide loading in glass. 
WSRC-TR-2001-00148

Page 13 of 25

Table 6 - PCCS Results for Frit 320-A

\begin{tabular}{|c|c|c|c|c|c|c|}
\hline & \multirow{2}{*}{\multicolumn{3}{|c|}{$\begin{array}{l}\text { Nominal Wash } \\
\text { Waste Loading } \\
\end{array}$}} & \multirow{2}{*}{\multicolumn{3}{|c|}{$\begin{array}{c}\text { Underwashed } \\
\text { Waste Loading }\end{array}$}} \\
\hline & & & & & & \\
\hline & Minimum & Nominal & Maximum & Minimum & Nominal & Maximum \\
\hline $\begin{array}{l}\text { Waste } \\
\text { Loading, \% }\end{array}$ & 22 & 25 & 30 & 22.5 & 25 & 30.5 \\
\hline $\begin{array}{l}\text { Viscosity, } \\
\text { Poise at } \\
1150^{\circ} \mathrm{C}\end{array}$ & 34.4 & 30 & 24.7 & 32.1 & 28.3 & 22.3 \\
\hline Liquidus, ${ }^{\circ} \mathrm{C}$ & 940 & 972 & 1020 & 942 & 969 & 1020 \\
\hline$\Delta G_{p}$ & -11.8 & -11.7 & -11.4 & -12.2 & -12.1 & -11.9 \\
\hline Homogeneity & 212 & 219 & 230 & 212 & 219 & 230 \\
\hline $\begin{array}{l}\text { Glass } \mathrm{Al}_{2} \mathrm{O}_{3} \\
\text { Conc. (wt \%) }\end{array}$ & 3.7 & 4.3 & 5.1 & 3.7 & 4.2 & 5 \\
\hline $\begin{array}{l}\sum \text { Alkali in } \\
\text { Glass (wt\%) }\end{array}$ & 19.7 & 19.7 & 19.6 & 20.1 & 20.2 & 20.2 \\
\hline $\begin{array}{l}\text { Glass } \mathrm{B}_{2} \mathrm{O}_{3} \\
\text { Conc. (wt } \% \text { ) }\end{array}$ & $>5$ & $>5$ & $>5$ & $>5$ & $>5$ & $>5$ \\
\hline
\end{tabular}


WSRC-TR-2001-00148

Page 14 of 25

Figure 4 - Graph of Melt Rate versus Alkali Content for MB3 Glasses

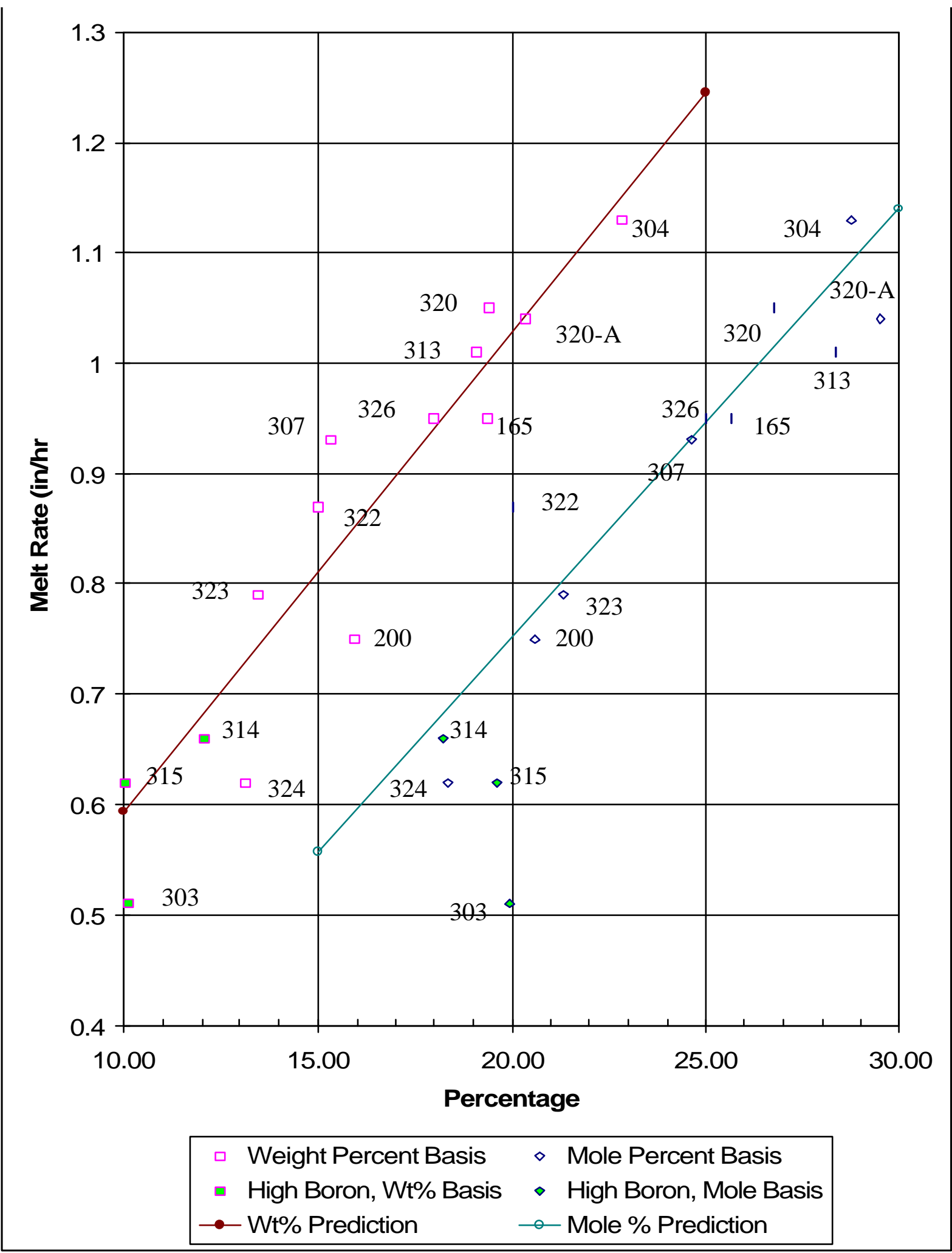


WSRC-TR-2001-00148

Page 15 of 25

\section{Processing Changes}

The melt-rate testing failed to identify alternative acid-addition strategies or redox adjustments that significantly improved the melt rate for MB3. However, the melter feed produced from underwashed sludge did melt significantly faster, and overwashed sludge melted slower (for a specific frit composition). This is consistent with testing that demonstrated that a frit with higher alkali content would lead to a faster melting glass. Underwashing the sludge will lead to higher sodium content in the sludge and the glass, which could lead to higher melt rates, assuming that the rates measured by the melt-rate furnace are directly translatable to DWPF. However, it is not clear whether there is a larger impact if the additional sodium comes from the frit or from the sludge.

\section{Modifications to Sludge Produced in the Extended Sludge Processing (ESP) Facility}

Processing an underwashed sludge leads to a significant increase in melt rate $(20 \%)$ relative to the Frit 200 baseline using the nominal sludge, while switching to a more washed sludge leads to a significant decrease in melt rate (-18\%). The underwashed sludge is approximately $2 \mathrm{wt} \%$ higher in sodium than the nominal sludge, which leads to an increase of approximately $0.5 \mathrm{wt} \%$ sodium in glass. Thus, a small increase in sodium led to a significant increase in melt rate as determined by the melt rate furnace test methodology.

Although underwashing may lead to increased melt rate, there are a number of other issues that need to be addressed prior to processing underwashed sludge in DWPF. Sludge washing is necessary to prepare the sludge for processing in DWPF. Before being fed to the DWPF, the waste sludge is processed in the tank farms to remove excess aluminum and soluble chemicals. These two processing steps are termed Extended Sludge Processing (ESP). First caustic is added to dissolve the insoluble aluminum solids, then an inhibited alkaline water wash to remove dissolved solids (sodium, nitrite, nitrate, chloride, fluoride, sulfate, etc.). If underwashed sludge were fed to DWPF, there are a number of issues that could significantly impact processing including:

1. Lower waste loading of radioactive waste components in glass.

2. Higher corrosion rate in melter offgas system (more fluoride, chloride).

3. Higher aluminum content may lead to lower melt rate.

4. Higher hydrogen generation in SRAT and SME.

5. Longer neutralization and processing time in SRAT and SME.

6. Higher offgas generation in melter, which may impede melt rate.

\section{Modifications to Sludge Processing in DWPF}

The results of the testing to determine whether the processing changes had any impact on melt rate are summarized in Tables 7 and 8 . Process changes based on adding formic acid only has a small (4\%) increase in melt rate relative to the Frit 200 baseline. Changing processing by adding sugar actually led to a decrease in melt rate (-9\%), presumably caused by foaming. 
WSRC-TR-2001-00148

Page 16 of 25

Although sugar did not have a positive benefit in the testing with MB3 sludge, sugar did have a significant impact on testing with the very oxidizing MB2 sludge. MB3 is high in noble metals compared to MB2, which may lead to a high generation of hydrogen during DWPF SRAT and SME processing. The hydrogen generation rate can be lowered by changing the acid mix to add more nitric acid. If this produces a melter feed that is too oxidizing, sugar could be added to return the glass redox back to $0.2 \mathrm{Fe}^{+2} / \Sigma \mathrm{Fe}$ to maximize the melt rate.

Table 7 - Melt-Rate Estimate of Process Changes based on Melt-rate Furnace Tests

\begin{tabular}{|l|c|c|c|c||}
\hline Processing & Nominal & Formic only & Underwashed & Overwashed \\
\hline \hline Linear Melt Rate, in./h & 0.57 & 0.59 & 0.68 & 0.47 \\
\%Increase & & $4 \%$ & $20 \%$ & $-18 \%$ \\
\hline Volumetric Melt Rate, in. ${ }^{3} / \mathrm{h}$ & 11.0 & 12.9 & 15.1 & 12.6 \\
\%Increase & & $17 \%$ & $37 \%$ & $15 \%$ \\
\hline Measured Redox, $\mathrm{Fe}^{+2} / \mathrm{Fe}$ & 0.17 & 0.18 & 0.12 & 0.14 \\
\hline
\end{tabular}

Table 8 - Melt-Rate Estimate of Adding Sugar, Based on Melt-Rate Furnace Tests

\begin{tabular}{||l|c|c|c||}
\hline \hline & $\begin{array}{c}\text { Sugar Added } \\
\text { (g sugar/g glass) }\end{array}$ & $\begin{array}{c}\text { Melt Rate } \\
\text { (in./h) }\end{array}$ & $\begin{array}{c}\text { Melt Rate } \\
\text { (in. }{ }^{\mathbf{3} / \mathbf{h})}\end{array}$ \\
\hline \hline Baseline Process & 0.000 & 0.75 & 11.0 \\
\hline Baseline Process with Sugar & 0.012 & 0.70 & 9.2 \\
\hline
\end{tabular}

\section{Evaluate Performance of Glasses Using Glass Models and Performance Testing}

Document: WSRC-TR-2001-00131, Melt Rate Improvement for DWPF MB3: Frit Development and Model Assessment, D. K. Peeler et al., March 30, 2001.

A report was written to summarize the work that was completed to evaluate these potential frits using the current DWPF PCCS models and to evaluate the durability of the glasses using measured product consistency test (PCT) analyses. To simplify the discussion, this will focus only on the eight frits tested during the final melt-rate furnace testing.

Table 9 summarizes the PCT results for the MB3 glasses made with $\mathrm{U}_{3} \mathrm{O}_{8}$. Note that all of the glasses had normalized elemental releases below $2 \mathrm{~g} / \mathrm{L}$, which is well below the Environmental Assessment (EA) glass standard ${ }^{12}$. The glass with the highest PCT release rate (lowest durability) was the Frit 304 glass (quenched) using the underwashed MB3 sludge (25.5 wt\% loading) with a measured sodium release rate of $1.82 \mathrm{~g} / \mathrm{L}$. 
WSRC-TR-2001-00148

Page 17 of 25

Table 9 - PCT Results of MB3 Glasses Made with $\mathrm{U}_{3} \mathrm{O}_{8}$

\begin{tabular}{|c|c|c|c|c|c|c|c|c|}
\hline & \multicolumn{4}{|c|}{ Quenched } & \multicolumn{4}{|c|}{ Centerline Cooled } \\
\hline Glass ID & $\begin{array}{c}\mathbf{N L} \\
\mathbf{B}(\mathrm{g} / \mathrm{L})\end{array}$ & $\begin{array}{c}\mathbf{N L} \\
\mathbf{L i}(\mathrm{g} / \mathrm{L})\end{array}$ & \begin{tabular}{|c|}
$\mathbf{N L}$ \\
$\mathrm{Na}(\mathrm{g} / \mathrm{L})$ \\
\end{tabular} & \begin{tabular}{|c|}
$\mathbf{N L}$ \\
$\mathrm{Si}(\mathrm{g} / \mathrm{L})$ \\
\end{tabular} & $\begin{array}{c}\mathbf{N L} \\
\mathbf{B}(\mathrm{g} / \mathrm{L})\end{array}$ & \begin{tabular}{|c|}
$\mathbf{N L}$ \\
$\mathrm{Li}(\mathrm{g} / \mathrm{L})$
\end{tabular} & \begin{tabular}{|c|}
$\mathrm{NL}$ \\
$\mathrm{Na}(\mathrm{g} / \mathrm{L})$
\end{tabular} & $\begin{array}{c}\mathbf{N L} \\
\mathrm{Si}(\mathrm{g} / \mathrm{L})\end{array}$ \\
\hline ARM & 0.50 & 0.61 & 0.54 & 0.29 & $\overline{\mathrm{NA}}$ & $\overline{\mathrm{NA}}$ & $\overline{\mathrm{NA}}$ & $\overline{\mathrm{NA}}$ \\
\hline EA (this study) & 16.80 & 9.26 & 13.25 & 3.88 & NA & NA & NA & NA \\
\hline $\begin{array}{l}\text { Underwashed } \\
\text { MB3 Glasses }\end{array}$ & \multicolumn{4}{|c|}{$\begin{array}{l}\text { All results are bias corrected } \\
\text { compositional measurements }\end{array}$} & \multicolumn{4}{|c|}{$\begin{array}{l}\text { All results are bias corrected } \\
\text { compositional measurements }\end{array}$} \\
\hline U165 & 1.05 & 1.04 & 1.23 & 0.65 & 1.00 & 1.04 & 1.11 & 0.63 \\
\hline U200 & 0.85 & 0.84 & 0.87 & 0.51 & 0.78 & 0.78 & 0.79 & 0.49 \\
\hline U304 & 1.06 & 1.23 & 1.82 & 0.88 & 0.98 & 1.21 & 1.59 & 0.79 \\
\hline U307 & 1.07 & 1.50 & 0.97 & 0.85 & 1.20 & 1.27 & 0.96 & 0.72 \\
\hline U314 & 1.29 & 1.33 & 0.82 & 0.38 & 1.18 & 1.20 & 0.79 & 0.38 \\
\hline U320 & 1.02 & 1.16 & 1.28 & 0.75 & 0.96 & 1.22 & 1.18 & 0.78 \\
\hline U326 & 1.14 & 1.23 & 1.35 & 0.78 & 1.16 & 1.30 & 1.26 & 0.80 \\
\hline
\end{tabular}

In terms of durability, the decision as to whether to select a candidate frit may be based on the answers to the following three tests:

(1) Does the glass "pass" the current SME acceptability durability criterion ${ }^{13}$. That is, does the glass, based on a measured composition, have a predicted $\Delta \mathrm{G}_{\mathrm{P}}>-12.72$ (i.e., the most conservative of the element release limits at the Property Acceptability Region (PAR))?

(2) Does the model predict the PCT well? That is, does the measured PCT result lie within the 95\% confidence intervals for individual PCT results?

(3) Is the release for the glass produced from the candidate frit less than EA (with the appropriate confidence levels applied)?

All of the highest melt-rate frits, except Frit 304, satisfy the above three tests. Glasses (at 25.5 wt\% loading) produced using Frits 320, 165, and 200 are all well predicted by the durability model, and they are within the 95\% confidence intervals shown in Figure 5. It is recommended that a variability study be performed for any frit prior to DWPF implementation (with the exception of Frit 200) to ensure that glasses made from a new frit at various waste loadings (and accounting for MB3 sludge variation) are well predicted by the durability model and have low PCT leach rates. 
WSRC-TR-2001-00148

Page 18 of 25

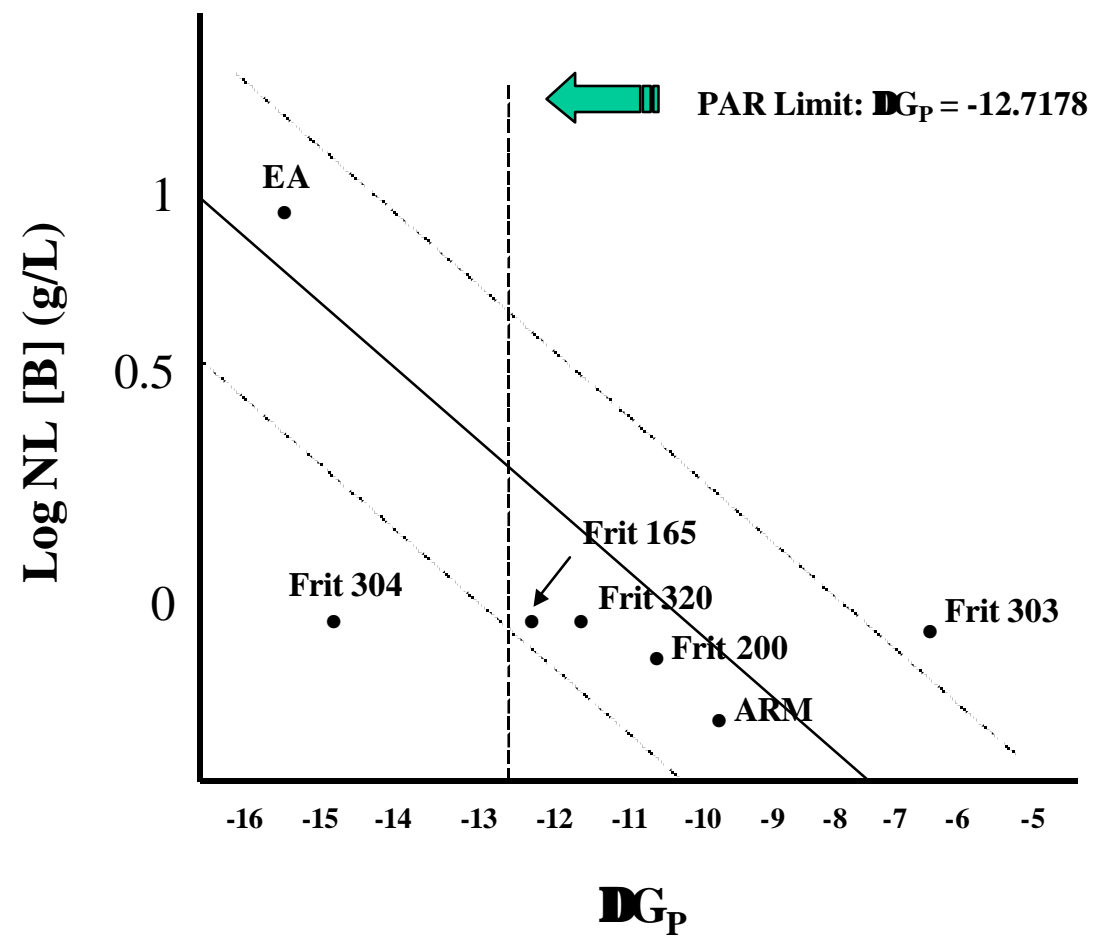

Figure 5 - Schematic of $\Delta G_{P}$ versus Log NL [B] (g/L) for Various Frits

Frit 304 poses a more difficult challenge in terms of SME acceptability for durability. Glass produced from Frit 304 and MB3 "fails" the first two tests for SME acceptability. That is, its predicted $\Delta \mathrm{G}_{\mathrm{P}}$ is more negative than the $-12.72 \mathrm{PAR}$ limit $\left(\Delta \mathrm{G}_{\mathrm{P}}=-13.79\right.$ and -14.24 for the nominal and underwashed MB3 sludge cases, respectively), and it lies outside the $95 \%$ confidence intervals, indicating that the model does not predict its PCT release well.

Although $\Delta \mathrm{G}_{\mathrm{P}}$ predictions would currently restrict DWPF from processing MB3 sludge with Frit 304, the measured normalized elemental releases indicate that glasses produced from either the nominal or underwashed MB3 sludge (at $25.5 \mathrm{wt} \%$ loading and for both thermal heat treatments) are $<2 \mathrm{~g} / \mathrm{L}$ (for all reportable elementals), which are still well below that of EA (approximately $16.7 \mathrm{~g} / \mathrm{L}$ for B). The data also indicated no significant difference between the quenched and centerline-cooled PCTs for either the nominally washed or the underwashed MB3 sludge cases.

The selection of an alternative frit to improve melt rate for MB3 will ultimately be influenced by the relative increase in melt rate that one frit has over the current baseline, the acceptable risk level one is willing to take, and/or budget/schedule restrictions. Based on this assessment, budget/schedule impacts would be minimized by selecting a frit that "passes" the current SME acceptability criteria for durability. However, this path may result in a frit that does not maximize the melt rate for MB3. Work should continue to address the technical issues identified (e.g., model prediction of durability for Frit 304) at some level, given that future sludge-only (or coupled) flowsheets may yield these same issues. If so, then frits can be rapidly developed and implemented while reducing technical risks. 
WSRC-TR-2001-00148

Page 19 of 25

\section{EVALUATION OF ALTERNATE FRIT COMPOSITIONS}

The decision on which frit to change to is not simple. If the melt rate were the only parameter to consider, then Frit 304 would be the best choice because it is the fastest melting for MB3 (based on small-scale testing). However, melt rate and glass durability both are highly correlated with the total alkali content of the glass. Higher total alkali contents appear to increase melt rate and usually lower durability. Thus, the fastest melting glass may be the least durable (but not necessarily unacceptable). There must be assurance that the recommended frit does not negatively impact the glass product or processing.

Another concern is that the results of this testing will not scale up to DWPF. There is no experience in predicting the actual melt-rate increase in a DWPF melter based on this $1 / 300^{\text {th }}$ scale testing with dried melter feeds. Further testing in a slurry-fed melt-rate furnace and in the 786-A minimelter would provide more confidence that the melt-rate increase measured in the melt-rate furnace will scale up to DWPF.

Table 10 provides a partial list of the current DWPF PAR limits for glass properties as predicted by PCCS. These must be met to ensure that DWPF is capable of producing an acceptable glass product. Because of the conservatism in many of the PCCS models, a failure to meet a glassproperty limit does not necessarily lead to a glass that could not be processed. However, since the glass properties are not directly measured in DWPF, reliance on the models is necessary.

Table 10 - PAR Limits for Various Glass Properties

\begin{tabular}{||l|c||}
\hline \hline Property & PAR Limit \\
\hline \hline $\mathrm{T}_{\mathrm{L}}$ & $<1024.95^{\circ} \mathrm{C}$ \\
\hline Homogeneity & $>210.92$ \\
\hline$\Delta \mathrm{G}_{\mathrm{P}}$ (durability) & $>-12.7178$ \\
\hline$\eta_{1150^{\circ} \mathrm{C}}$ & $21.5-105.4$ Poise \\
\hline
\end{tabular}

\section{SUMMARY OF TEST RESULTS}

Table 11 attempts to summarize the results of the melt-rate tests completed in FY01. The most important needs are for a frit change that leads to a faster melting, durable glass within the required DWPF processing limits for liquidus temperature and viscosity. Any area highlighted should be scrutinized and will be discussed below. Only the six fastest melting frits will be discussed.

Frit 304 is the fastest melting frit based on crucible and melt-rate furnace testing. This frit produces glass that is predicted to meet DWPF constraints for liquidus ${ }^{1}$, viscosity, homogeneity, and $\mathrm{Al}_{2} \mathrm{O}_{3}$ concentration. The potentially negative issue with Frit 304 is that the PCCS predicted

\footnotetext{
${ }^{1}$ It should be noted that the predictions of liquidus assume that all MB3 glasses assessed in this study lie within the spinel primary phase field. This may or may not be the case. If not, the applicability of the current $\mathrm{T}_{\mathrm{L}}$ model used for these predictions may not be valid.
} 
WSRC-TR-2001-00148

Page 20 of 25

$\Delta \mathrm{G}_{\mathrm{P}}$ is -13.8 (based on target composition), outside the current acceptable region. This is a region where durability is not predicted well by the current model. Based on measured PCT values, all normalized elemental releases are less than $<2 \mathrm{~g} / \mathrm{L}$. However, the current DWPF acceptance criterion for durability would not allow this glass to be processed. If one were to seriously consider Frit 304 as potential frit candidate for MB3, an alternative technique that could be used by DWPF to address the SME acceptability issue must be developed. Alternative methods exist to derive constraints that would allow DWPF to utilize Frit 304. Alternatives include but are not limited to: (i) developing a non-parametric model over the composition region and/or (ii) revising the current DWPF durability model. Regardless of the pathway selected, the development of a technical foundation to support replacing the current durability acceptance criteria may be a nontrivial task. Although the options to address the technical issues with SME durability acceptance for Frit 304 are not trivial, the technical team does feel that they can and should be adequately addressed since this has promise to open up the operating window. In addition, prior to implementing Frit 304, an expanded variability model must be performed to reach compositional regions that were not covered by the Frit 200 / MB3 variability study ${ }^{14}$.

Frit 320 is the second-fastest melting frit based on melt-rate furnace testing. This frit produces glass that is predicted to meet all DWPF constraints, including liquidus, viscosity, homogeneity, durability and $\mathrm{Al}_{2} \mathrm{O}_{3}$ concentration. Also, the waste loading range for both nominal and underwashed sludge is acceptable. As with all frits except Frit 200, an expanded variability model must be performed to reach compositional regions that were not covered by the Frit 200 / MB3 variability study ${ }^{14}$.

Frit 313 is the third-fastest melting frit based on melt-rate furnace testing. This frit produces glass that is predicted to meet all DWPF constraints, including liquidus, viscosity, homogeneity, durability, and $\mathrm{Al}_{2} \mathrm{O}_{3}$ concentration. Like Frit 320, the waste-loading range for both nominal and underwashed sludge is acceptable. As with all frits except Frit 200, an expanded variability model must be performed to reach compositional regions that were not covered by the Frit 200 / MB3 variability study ${ }^{14}$.

Frits 165, 326, and 307 are next fastest after Frit 313 based on melt-rate furnace testing. These frits all produce glass that is predicted to meet all DWPF constraints, including liquidus, viscosity, homogeneity, durability, and $\mathrm{Al}_{2} \mathrm{O}_{3}$ concentration. The waste-loading range for both nominal and underwashed sludge is acceptable. As with all frits except Frit 200, an expanded variability model must be performed to reach compositional regions that were not covered by the Frit 200 / MB3 variability study ${ }^{14}$. Frit 165 glass (using the targeted nominal washed MB3 sludge) is approaching the PCCS $\Delta \mathrm{G}_{\mathrm{P}}$ limit of -12.7 . 
WSRC-TR-2001-00148

Page 21 of 25

Table 11 - Summary of Results for FY01 Melt-Rate Tests

\begin{tabular}{|c|c|c|c|c|c|c|c|c|}
\hline Frit & 304 & 320 & 313 & 326 & 165 & $\begin{array}{c}307 \\
\end{array}$ & 200 & 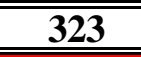 \\
\hline $\begin{array}{l}\text { Linear Melt Rate, } \\
\text { in./h (\%Increase) }\end{array}$ & $\begin{array}{l}1.13 \\
51 \%\end{array}$ & $\begin{array}{l}1.05 \\
40 \%\end{array}$ & $\begin{array}{l}1.01 \\
35 \%\end{array}$ & $\begin{array}{l}0.95 \\
27 \%\end{array}$ & $\begin{array}{l}0.95 \\
27 \%\end{array}$ & $\begin{array}{l}0.93 \\
24 \%\end{array}$ & 0.75 & $\begin{array}{c}0.62 \\
-17 \%\end{array}$ \\
\hline $\begin{array}{l}\text { Measured PCT B } \\
\text { Release (quenched), } \\
\text { g/L, nominal MB3 } \\
\text { sludge }\end{array}$ & 1.07 & 1.00 & 1.30 & 1.05 & 0.99 & 0.89 & 0.77 & 0.71 \\
\hline $\begin{array}{l}\text { Measured PCT B } \\
\text { Release (centerline- } \\
\text { canister cooled), g/L, } \\
\text { nominal MB3 sludge }\end{array}$ & 1.05 & 0.98 & 1.78 & 1.07 & 0.92 & 0.94 & 0.73 & 0.61 \\
\hline$\Delta \mathrm{G}_{\mathrm{P}}$ & -13.8 & -11.8 & -11.1 & -11.3 & -12.3 & -9.2 & -10.1 & -8.5 \\
\hline $\begin{array}{l}\text { Predicted Viscosity, }{ }^{(a)} \\
\text { Poise (at } 1150^{\circ} \mathrm{C} \text { ) }\end{array}$ & 32.4 & 40.7 & 37.6 & 44.7 & 33.1 & 41.1 & 61.9 & 73.1 \\
\hline $\begin{array}{l}\text { Measured Viscosity, } \\
\left.\text { Poise (at } 1150^{\circ} \mathrm{C}\right)\end{array}$ & 43.05 & 38.55 & 35.31 & $\begin{array}{c}\text { Not } \\
\text { measured }\end{array}$ & 34.86 & 32.88 & $\begin{array}{c}\text { Not } \\
\text { measured }\end{array}$ & $\begin{array}{c}\text { Not } \\
\text { measured }\end{array}$ \\
\hline Homogeneity $^{(b)}$ & 227 & 220 & 220 & 218 & 217 & 220 & 217 & 220 \\
\hline Liquidus Temp, ${ }^{\circ} \mathrm{C}^{(\mathrm{c})}$ & 995 & 972 & 967 & 972 & 983 & 970 & 977 & 973 \\
\hline $\begin{array}{l}\text { Waste Loading } \\
\text { Range, nominal } \\
\text { sludge }\end{array}$ & $\begin{array}{c}\text { No } \\
\text { Window }\end{array}$ & $\begin{array}{c}22.0- \\
30.0\end{array}$ & $\begin{array}{l}22.0- \\
30.5\end{array}$ & $\begin{array}{c}22.5- \\
30.0\end{array}$ & $\begin{array}{c}23.0- \\
29.0\end{array}$ & $\begin{array}{l}22.0- \\
30.5\end{array}$ & $\begin{array}{l}23.0- \\
29.5\end{array}$ & $\begin{array}{c}22.0- \\
30.0\end{array}$ \\
\hline $\begin{array}{l}\text { Waste Loading } \\
\text { Range, underwashed } \\
\text { sludge }\end{array}$ & $\begin{array}{c}\text { No } \\
\text { Window }\end{array}$ & $\begin{array}{c}22.5- \\
30.5\end{array}$ & $\begin{array}{c}22.5- \\
31.0\end{array}$ & $\begin{array}{r}23.0- \\
30.5\end{array}$ & $\begin{array}{l}25.0- \\
29.5\end{array}$ & $\begin{array}{l}22.5- \\
30.5\end{array}$ & $\begin{array}{c}23.5- \\
30.0\end{array}$ & $\begin{array}{c}22.5- \\
30.5\end{array}$ \\
\hline $\begin{array}{l}\text { Variability Study } \\
\text { needed? }\end{array}$ & Yes & Yes & Yes & Yes & Yes & Yes & No & Yes \\
\hline $\begin{array}{l}\mathrm{Al}_{2} \mathrm{O}_{3} \text { in glass (target } \\
\text { composition) }\end{array}$ & 6.03 & 4.34 & 4.34 & 4.35 & 4.35 & 4.36 & 4.35 & 4.30 \\
\hline
\end{tabular}

(a) Viscosity predicted for a $25.5 \mathrm{wt} \%$ nominal sludge oxide loading in glass (target composition).

(b) Homogeneity predicted for a $25.5 \mathrm{wt} \%$ nominal sludge oxide loading in glass (target composition).

(c) Liquidus predicted for a $25.5 \mathrm{wt} \%$ nominal sludge oxide loading in glass (target composition) assuming a spinel primary phase. 
WSRC-TR-2001-00148

Page 22 of 25

\title{
RECOMMENDATIONS
}

Based on the above data and model assessments, we recommend the following steps to improve the melt rate for MB3:

A. Replace Frit 200 with Frit 320 for MB3. Test the new frit in the 786-A minimelter, slurryfed melt-rate furnace (if melt rate is measured in the minimelter test, the slurry fed melt rate test is not needed) and in the shielded cells demonstration that is planned. Augment the variability study for MB3 glass to include regions that include this new frit. Assess the applicability of the $\mathrm{T}_{\mathrm{L}}$ predictions for this compositional region.

\begin{abstract}
AND
B. Initiate research to address the SME acceptability issues restricting the recommendation of Frit 304 for MB3. Issues that should be addressed include developing an alternative durability model (or enhancement of the existing model) that could be implemented into DWPF to supplant the current model.
\end{abstract}

It is the consensus of the melt-rate team that Frit 320 is the best overall choice at the present time for use in DWPF for MB3. However, Frit 304, which actually improves the melt rate more than Frit 320, could potentially be a better choice if durability issues are resolved. In addition, reduced washing has a potentially high impact for increasing melt rate and minimizing water generation in the tank farms but can not be recommended without additional research.

\section{CONCLUSIONS}

The melt-rate testing in FY01 demonstrated that melt rate can be improved by using a frit other than Frit 200 for MB3. The recommended frit, Frit 320, melted significantly faster than Frit 200 and the durability of this glass is accurately predicted by PCCS. The frit that melted the fastest in the melt-rate testing was Frit 304. However, a potentially negative issue with Frit 304 is that the PCCS predicted $\Delta \mathrm{G}_{\mathrm{p}}$ is outside the current acceptable region. This glass would not be processable based on current DWPF acceptance criterion even though measured normalized elemental releases from the PCT were below $2 \mathrm{~g} / \mathrm{L}$.

No significant melt-rate improvement was identified by producing a much more reducing glass through the addition of sugar as a reductant. A change to a formic-acid-only flowsheet would lead to a very small increase in melt rate. The addition of sugar as an additional reductant would likely create a glass that is too reducing $\left(>0.33 \mathrm{Fe}^{+2} / \Sigma \mathrm{Fe}\right)$ for the DWPF melter. Additional work (e.g., melter offgas flammability, melter-feed rheology, and redox correlation) would need to be performed in this area.

The list below summarizes the most important results from this testing:

- The melt-rate furnace is capable of measuring the relative melt rate and the height of the volume expansion. 
WSRC-TR-2001-00148

Page 23 of 25

- Frit-composition changes can be used to improve the melt rate, with Frit 304 melting the fastest of the frits tested with dried MB3 melter feed.

- Changing the ratio of nitric acid to formic acid only slightly increases the melt rate.

- An increase in alkali correlated strongly to an increase in melt rate. This is true whether the additional alkali is in the frit or the sludge.

- The PCCS durability model does not accurately predict the release rate of $\mathrm{B}, \mathrm{Na}, \mathrm{Li}$, and $\mathrm{Si}$ as measured by the PCT for all of the frits used in this study. Note: The PCCS durability model is still adequate for use by DWPF since it is conservative. The model falsely rejected Frit 304 (the fastest melting frit) that in fact produced durable glass as measured by the PCT at a fixed waste loading. 
WSRC-TR-2001-00148

Page 24 of 25

\section{REFERENCES}

1 WSRC-TR-93-673, Rev. 1, Process/Product Models for the Defense Waste Processing Facility (DWPF): Part I. Predicting Glass Durability from Composition Using a Thermodynamic Hydration Energy Reaction Model (THERMO) (U), Volume 1, Jantzen, C.M., J.B. Pickett, K.G. Brown, T.B. Edwards, and D.C. Beam. 1995.

2 WSRC.TR-2000-0395, DWPF Macrobatch 2 Melt Rate Tests, M. E. Stone, D. P. Lambert, October 5, 2000.

3 Technical Task Request \#HLW/DWPF/TTR-00-0044, DWPF Macrobatch 3 Melt Rate Study.

4 WSRC-RP-2001-00183, Increase Melting Rate of DWPF Feed - Task Technical \& QA Plan, D. P. Lambert, D. K. Peeler, November 13, 2000 (first issued as WSRC-RP-2000-00080). T TFA TTP\# SR-1-6-WT-31

5 WSRC-TR-2000-00398, Revision 0, Sludge Batch 2 (Macrobatch 3) Flowsheet Studies With Simulants (U), D. C. Koopman, October 9, 2000.

6 TFA-IMM-01-001, Glass Frit Calculations for Macrobatch 3, J. D. Vienna, January 11, 2001.

${ }^{7}$ Review of PNNL Work on Alternative Reductants and Melter Tank Bubblers, J.M. Perez, Pacific Northwest National Laboratory, January, 2001.

${ }^{8}$ DPST-88-952, Glass Composition and Frit Formulation Developed for DWPF, C. M. Jantzen, 1988.

9 HLW-SDT-2000-00128, Revision 0, Position Paper on Sludge Batch 2 Qualification Strategy and Simulant Composition, May 9, 2000.

10 WSRC-RP-97-34, K. G. Brown, C. M. Jantzen, and J. B. Pickett, The Effects of Formate and Nitrate on Reduction/Oxidization (Redox) Process Control for the Defense Waste Processing Facility (DWPF) (U), February 5, 1997.

11 WSRC-TR-2001-00146, Melt Rate Improvement for DWPF MB3: Melt Rate Furnace Testing, M. E. Stone, J. E. Josephs, March 30, 2001.

12 WSRC-TR-92-346, Rev. 1, Characterization of the DWPF Environmental Assessment (EA) Glass Standard Reference Material (U), Jantzen, C.M., N. E. Bibler, D. C. Beam, C. L. Crawford and M. A. Pickett, 1993.

13 WSRC-TR-95-0364, SME Acceptability Determination for DWPF Process Control (U), Revision 3, K. G. Brown and R. L. Postles, 1996.

14 WSRC-TR-2000-00351, Summary of Results for Macrobatch 3 Variability Study (U), Rev. 0., J.R. Harbour, T.B. Edwards, and R.J. Workman, 2000. 
WSRC-TR-2001-00148

Page 25 of 25

\section{Distribution}

W. D. Kerley, 704-S

D. C. Witt, 704-1T

J. F. Ortaldo, 704-S

M. E. Stone, 704-1T

R. E. Edwards, 704-3N

D. P. Lambert, 704-1T

M. R. Norton, 704-27S

M. F. Williams, 704-1T

J. E. Occhipinti, 704-27S

D. C. Koopman, 704-1T

J. F. Sproull, 704-30S

T. K. Snyder, 773-42A

D. C. Iverson, 704-30S

R. J. O'Driscoll, 704-30S

J. J. Connelly, 773-41A

L. M. Papouchado, 773-A

K. G. Brown, 704-1T

E. W. Holtzscheiter, 773-A

D. R. Best, 773-41A

R. H. Spires, 773-A

D.K. Peeler, 773-43A

T.H. Lorier, 773-23A

D. A. Crowley, 773-43A

D. H. Miller, 786-1A

S. L. Marra, 704-1T

T. B. Edwards, 773-42A

D. F. Bickford, 773-43A

C. M. Jantzen, 773-A

J.C. George, 773-43A

Records (4)

VT QA File 